\title{
Chemically Active Elements of Reservoir Quartz Cement Trace Hydrocarbon Migration in the Mahu Sag, Junggar Basin, NW China
}

\author{
Linjun Huang, ${ }^{1,2}$ Yin Liu, ${ }^{3}$ Baoli Bian, ${ }^{4}$ Yongping Ma, ${ }^{2}$ Hailei Liu, ${ }^{4}$ Juanjuan Guo, ${ }^{2}$ \\ and Jian Cao iD 1 \\ ${ }^{1}$ State Key Laboratory for Mineral Deposits Research, School of Earth Sciences and Engineering, Nanjing University, \\ Nanjing 210023, China \\ ${ }^{2}$ PetroChina Research Institute of Petroleum Exploration and Development-Northwest, Lanzhou 730022, China \\ ${ }^{3}$ Key Laboratory of Deep Oil and Gas, School of Geosciences, China University of Petroleum, Qingdao, Shandong 266580, China \\ ${ }^{4}$ Exploration and Development Research Institute of Xinjiang Oilfield Company, Karamay, Xinjiang 834000, China
}

Correspondence should be addressed to Jian Cao; jcao@nju.edu.cn

Received 30 December 2020; Revised 5 March 2021; Accepted 19 March 2021; Published 8 April 2021

Academic Editor: Yingfang Zhou

Copyright (C) 2021 Linjun Huang et al. This is an open access article distributed under the Creative Commons Attribution License, which permits unrestricted use, distribution, and reproduction in any medium, provided the original work is properly cited.

Element exchange and enrichment during fluid-rock interactions are common, providing potentially novel proxies to trace hydrocarbon migration in addition to the traditional organic geochemistry tracers. However, the processes, mechanisms, and geological and geochemical fingerprints of these interactions are complex, hampering the applications of hydrocarbon migration tracers. To investigate such interactions, we conducted a petrological, mineralogical, and in situ and bulk geochemical study of authigenic quartz and whole-rock samples from the Mahu Sag, northwestern Junggar Basin, northwest China. We found that dissolution, clay and chlorite formation, and overgrowth occurred on quartz grains in hydrocarbon fluid migration pathways, suggestive of strong fluid-rock interactions. In situ quantitative elemental analysis of quartz grains revealed elemental enrichment (e.g., $\mathrm{Mn}, \mathrm{Fe}, \mathrm{Al}, \mathrm{Sr}$, and $\mathrm{W}$ ) in quartz overgrowth rims compared with their cores, indicating that migration of hydrocarbon-bearing fluids in reservoirs may promote elemental exchange between fluids and minerals. Whole-rock geochemical analysis showed that decreasing contents of some elements may reflect the direction of hydrocarbon-bearing fluid migration and can be monitored with three geochemical proxies, which are the $\mathrm{MnO}$ contents and $\mathrm{MnO} / \mathrm{Zr}$ and $\mathrm{Y} / \mathrm{Ho}$ ratios. Our data provide new constraints on fluid-rock interactions in petroleum reservoirs and have implications for using inorganic geochemical methods to trace hydrocarbon migration.

\section{Introduction}

Hydrocarbon fluid migration is the key link between hydrocarbon generation and accumulation. Numerous studies have been undertaken on hydrocarbon migration, including physical experiments [1-5], numerical simulations [6-12], coupling analysis of thermal, stress, and pressure fields [13-18], and organic geochemical and isotope studies [19, 20]. Physical and numerical simulations build a model from the perspective of forward modeling and then observe the migration process of hydrocarbon fluids in reservoirs by using experimental facilities or computer models $[8,9]$. Thermal, stress, and pressure field coupling analysis mainly involves assessing the direction of hydrocarbon migration using the fluid potential, crude oil density, formation water salinity, and other parameters based on the physical properties of hydrocarbon-bearing fluids [21-25]. Organic geochemistry indicators, including maturity indicators, nitrogen-containing compounds in crude oil, and fractionation effects on carbazole, pyrrole, and other compounds, are amongst the most efficient methods to trace hydrocarbon fluid migration [26-31]. However, due to mixing of multisource and multiphase hydrocarbons in superimposed basins and the effects of secondary modification, organic geochemical indicators are susceptible 

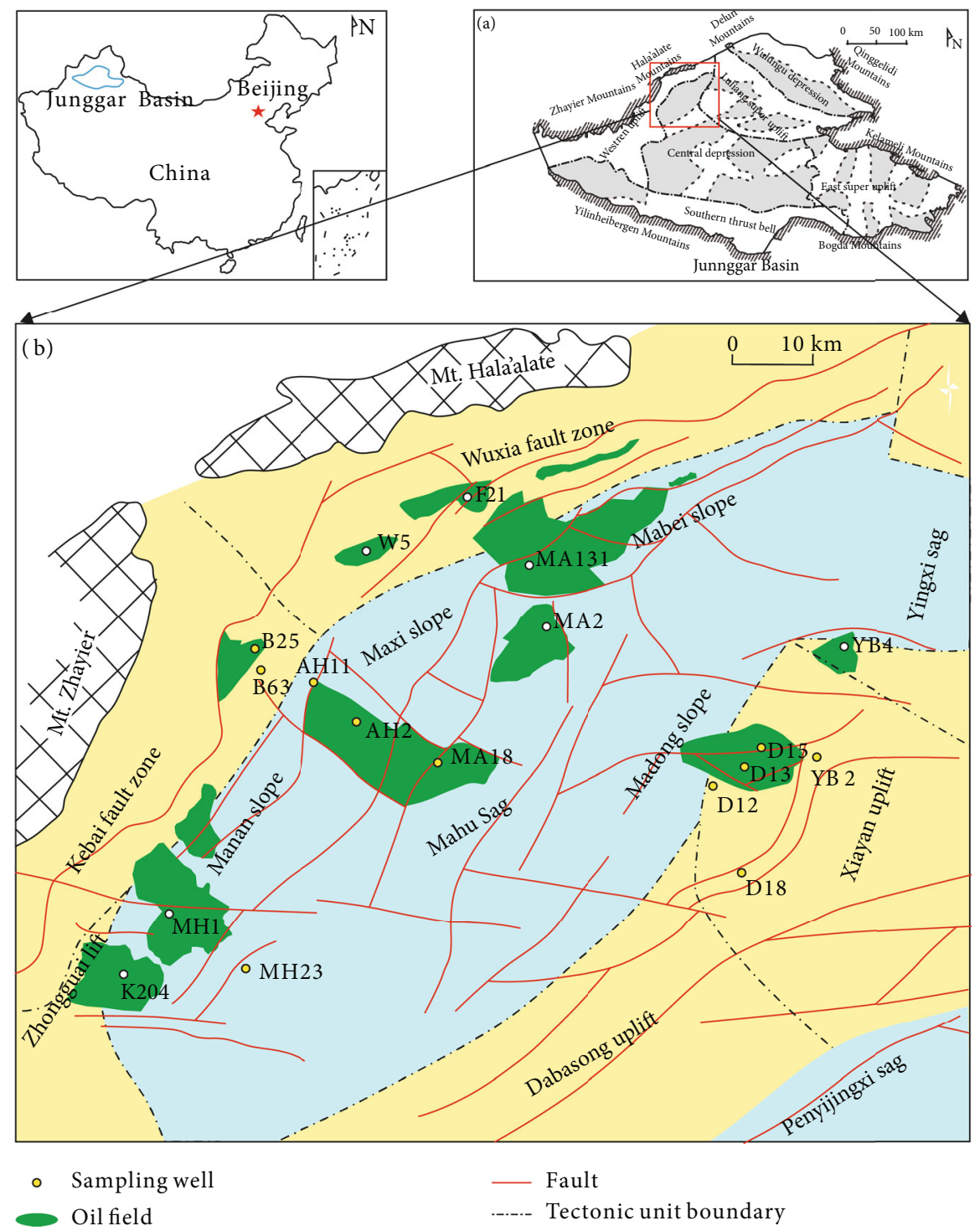

FIGURE 1: (a) Map showing the location and major tectonic units of the Junggar Basin. (b) Map showing the distribution of major oil fields and sampled wells in the Mahu Sag (modified after PetroChina Xinjiang Oilfield Company, 2019).

to complex geological processes $[32,33]$. Therefore, it is difficult to determine the direction of hydrocarbon migration based on only one indicator.

Studies have shown that strata through which fluids have migrated experience strong physical and chemical interactions between fluids and rocks, which then lead to changes in the composition, morphology, and other aspects of the rocks and minerals [34-36]. As such, these interactions can leave a record of the processes, direction, and strength of fluid migration [37-40]. When hydrocarbon-bearing fluids migrate in strata, organic inclusions can form in authigenic minerals in reservoirs. An increasing number of studies have investigated the effects of fluid-rock interactions and, in particular, the elemental and isotope geochemistry of authigenic minerals [41, 42], sources of hydrothermal fluids [43, 44], and rates and mechanisms of fluid-rock interactions [45]. In theory, geochemical changes recorded by authigenic minerals can record the migration of hydrocarbon-bearing fluids and reveal the processes of hydrocarbon migration. Therefore, such information is of significance in determining the migration direction of hydrocarbon fluids. However, the whole-rock geochemistry records only the averaged history of a hydrothermally modified rock. In contrast, in situ geochemical studies of authigenic minerals can provide more resolved information regarding fluid migration.

Elemental geochemistry has been used in recent studies to trace hydrocarbon fluid migration, based on rationale of interactions between organic fluids and inorganic minerals [46-48]. Most of these studies have focused on calcite or calcium carbonate cements in fault zones. However, studies of fluid migration in reservoirs with low contents of calcite and other diagenetic minerals remain limited. In addition, the distribution of elements in diagenetic minerals is heterogeneous, and hydrothermal fluids are likely to modify parts of the minerals, which requires an in situ analytical approach. 
TABle 1: Basic features of the Triassic Baikouquan Formation reservoir samples from the Mahu Sag, Junggar Basin.

\begin{tabular}{|c|c|c|c|c|}
\hline Well & Depth (m) & Lithology & Core characteristics & $\begin{array}{l}\text { Oil-bearing } \\
\text { characteristics }\end{array}$ \\
\hline B63 & $2452 / 2514$ & $\begin{array}{c}\text { Sandy } \\
\text { conglomerate }\end{array}$ & Grey conglomerate, the pebble is mainly lithic fragment and quartz & Oil stain \\
\hline B25 & 2318.1 & $\begin{array}{l}\text { Sandy } \\
\text { conglomerate }\end{array}$ & Grey conglomerate, the pebble is mainly lithic fragment and quartz & Oil stain \\
\hline YB2 & 4110.2 & $\begin{array}{l}\text { Sandy } \\
\text { conglomerate }\end{array}$ & $\begin{array}{l}\text { Greyish-green conglomerate, the pebble is mainly lithic fragment } \\
\text { and quartz }\end{array}$ & Oil stain \\
\hline $\mathrm{AH} 2$ & 3313.6 & $\begin{array}{l}\text { Sandy } \\
\text { conglomerate }\end{array}$ & $\begin{array}{l}\text { Greyish-green conglomerate, the pebble is mainly lithic fragment } \\
\text { and quartz }\end{array}$ & Oil stain \\
\hline AH11 & 2824.5 & $\begin{array}{l}\text { Sandy } \\
\text { conglomerate }\end{array}$ & $\begin{array}{l}\text { Greyish-green conglomerate, the pebble is mainly lithic fragment } \\
\text { and quartz }\end{array}$ & Oil stain \\
\hline D15 & $4245 / 4253.7$ & $\begin{array}{l}\text { Sandy } \\
\text { conglomerate }\end{array}$ & $\begin{array}{l}\text { Greyish-green conglomerate, the pebble is mainly lithic fragment } \\
\text { and quartz }\end{array}$ & Oil stain \\
\hline D12 & $4269.2 / 4267 / 4284$ & $\begin{array}{l}\text { Sandy } \\
\text { conglomerate }\end{array}$ & $\begin{array}{l}\text { Greyish-green conglomerate, the pebble is mainly lithic fragment } \\
\text { and quartz }\end{array}$ & Oil stain \\
\hline D18 & 4451.4 & $\begin{array}{l}\text { Sandy } \\
\text { conglomerate }\end{array}$ & $\begin{array}{l}\text { Greyish-green conglomerate, the pebble is mainly lithic fragment } \\
\text { and quartz }\end{array}$ & Oil stain \\
\hline D13 & 4209 & $\begin{array}{l}\text { Sandy } \\
\text { conglomerate }\end{array}$ & $\begin{array}{l}\text { Greyish-green conglomerate, the pebble is mainly lithic fragment } \\
\text { and quartz }\end{array}$ & Oil stain \\
\hline MH23 & 4078.9 & $\begin{array}{l}\text { Sandy } \\
\text { conglomerate }\end{array}$ & $\begin{array}{l}\text { Greyish-green conglomerate, the pebble is mainly lithic fragment } \\
\text { and quartz }\end{array}$ & Oil stain \\
\hline MA18 & 3905.8 & $\begin{array}{l}\text { Sandy } \\
\text { conglomerate }\end{array}$ & $\begin{array}{c}\text { Greyish-green conglomerate, the pebble is mainly lithic fragment } \\
\text { and quartz }\end{array}$ & Oil stain \\
\hline
\end{tabular}

In addition to calcite cement, quartz is common in terrigenous clastic sedimentary rocks, and diagenesis and hydrothermal fluids result in quartz overgrowths. Recent studies have proposed that the geochemistry of quartz overgrowths may reflect the characteristics of hydrothermal fluids [38]. However, the relationship between the geochemical composition of the quartz overgrowths and hydrocarbon migration remains unclear and requires further investigation.

Therefore, in this paper, we present a petrological, mineralogical, and in situ and whole-rock geochemical study of the Lower Triassic Baikouquan Formation, which is a new exploration target on the slope of the Mahu Sag, Junggar Basin, northwest China. We use these data to investigate the migration of hydrocarbon fluids in reservoirs based on the geochemistry of quartz cements.

\section{Geological Setting}

The Junggar Basin is located in northern Xinjiang Province and is an important part of the Central Asian Orogenic Belt, covering an area of $\sim 130,000 \mathrm{~km}^{2}$. The basin is surrounded by three fold and thrust belts, including the Zhayier and Hala'alat Mountains along its northwestern margin, the Qinggelidi and Kelameili Mountains along its northeastern margin, and the Bogda and Yilinheibiergen Mountains of the Tianshan along its southern margin (Figure 1(a)). The Junggar Basin comprises Carboniferous folded basement $[49,50]$ and sedimentary cover rocks, including Paleozoic, Mesozoic, and Cenozoic strata. The basin has experienced three main stages: development of a foreland basin in the late Carboniferous-Permian, an intracontinental depressional basin in the Triassic-Paleogene, and a rejuvenated foreland basin since the Neogene [51-53].

Several structural units occur in the Junggar Basin (Figure 1(a)), and the Mahu Sag is one of the largest depressions in the basin (Figure 1(a)) [54]. The slope of the Mahu Sag is the most favorable hydrocarbon accumulation area, where nearly one billion tons of oil have been discovered (Figure 1(b)). To the north, the slope area is bounded by the Wuxia (Wuerhe-Xiazijie) and Kebai (Karamay-Baikouquan) fault belts. The Yingxi Sag and Xiayan and Dabasong uplifts are located to the east of the Mahu Sag. According to drilling data, Neogene and Carboniferous strata are well developed in the Mahu Sag. Triassic strata unconformably overlie Permian strata. The source rocks in the Mahu Sag are mainly the lower Permian Jiamuhe and Fengcheng Formations $[55,56]$. The Jiamuhe Formation has its hydrocarbon generation center in the west of the Mahu Sag and thins gradually to the east, north, and south. The Fengcheng Formation has its hydrocarbon generation center in the north of the Mahu Sag and thins to the east and west. Hydrocarbon accumulation in the Mahu Sag involved three stages, during the Middle-Late Permian, Late Triassic, and Early Cretaceous $[57,58]$. The Triassic strata were generally deposited in the transgressive system of a lake basin, with alluvial fan and shallow-water fan-delta sediments deposited at the northwestern margin of the sag. The Baikouquan Formation $\left(\mathrm{T}_{1} b\right)$ consists mainly of red-brown and grey sandy conglomerates. 


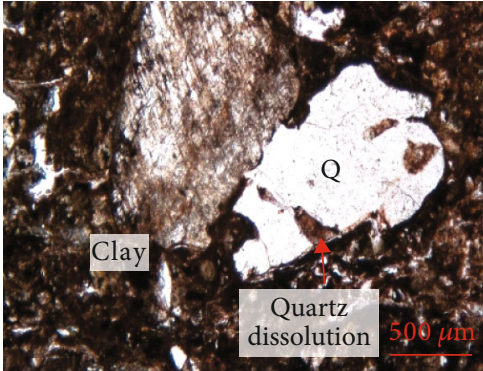

(a)

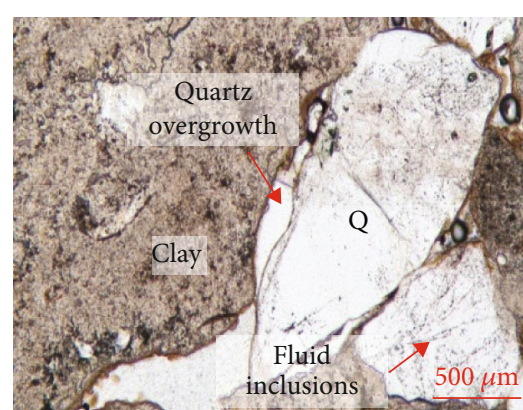

(b)

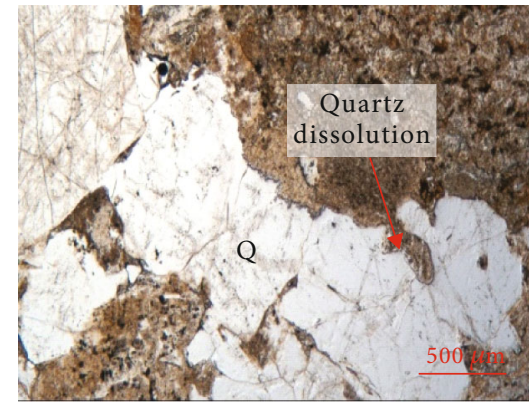

(c)

FIgURE 2: Morphological characteristics of quartz under the microscope. (a) Quartz replaced by and infilled with clay, with oil stains (sample B63; $2452 \mathrm{~m} ; \mathrm{T}_{1} b$; $5 \times$; plane-polarized light). (b) Inclusion-rich and oil-stained quartz overgrowth (sample D15; $4245 \mathrm{~m} ; \mathrm{T}_{1} b, 5 \times ;$ planepolarized light). (c) Quartz dissolved and replaced by clay, with oil stains (sample AH2; $3313.56 \mathrm{~m}$; $\mathrm{T}_{1} b$; 5×; plane-polarized light). $\mathrm{T}_{1} b=$ the lower Triassic Baikouquan Formation.

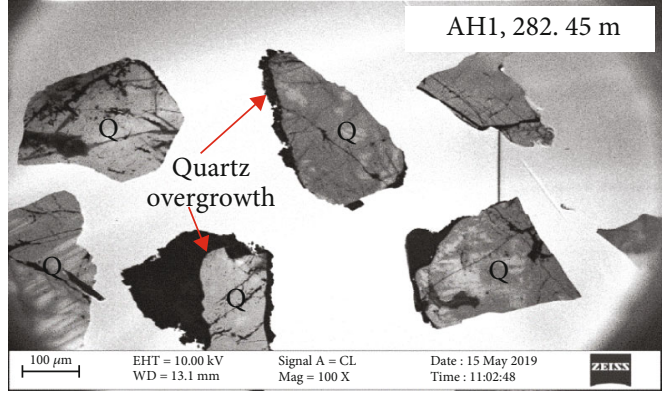

(a)

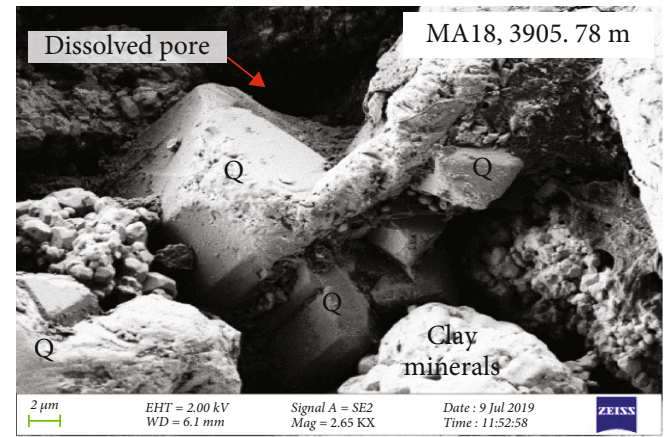

(c)

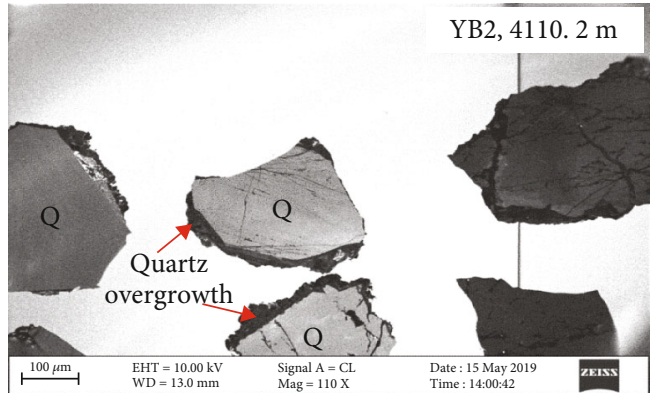

(b)

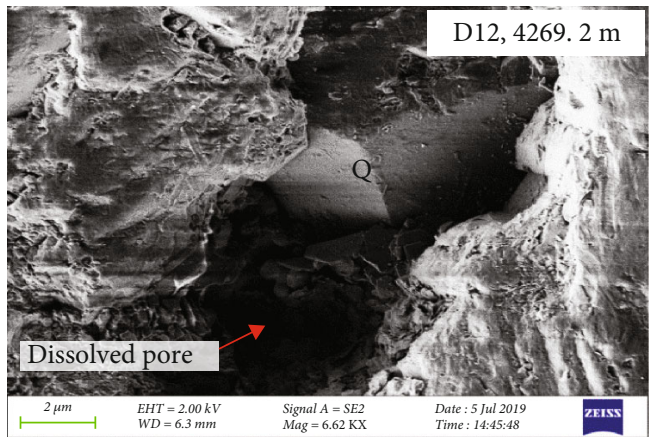

(d)

FIGURE 3: Core and rim features of quartz in cathodoluminescence (upper) and scanning electron microscopy (lower) images.

\section{Samples and Methods}

In this study, we collected 15 drill core samples of the Baikouquan Formation from 11 wells (MA18, MH23, AH2, AH11, B25, B63, D12, D13, D15, D18, and YB2) for mineralogical and geochemical studies. These samples are mainly grey or greyish green sandy conglomerates (Table 1). The locations of these wells are shown in Figure 1, and sample details are listed in Table 1. All samples were made into polished thin sections and powdered to $<200$ mesh $(74 \mu \mathrm{m})$ in an agate mortar.

The samples were examined under a polarizing microscope (Zeiss Axio Lab A1) at the China University of Petroleum (East China), Qingdao. Cathodoluminescence (CL) imaging was undertaken in the Beijing SHRIMP Center, using a Carl Zeiss Merlin Compact instrument coupled to a GATAN Mono CL4. Scanning electron microscopy (SEM) was undertaken at the Key Laboratory of Shale Hydrocarbons, Chinese Academy of Geological Sciences, Beijing, using a Zeiss Sigma 300 instrument. In situ microanalysis was conducted at Beijing Standard Energy Ltd. using a JEOL JXA8230 electron microprobe (major elements) and GeolasPro $193 \mathrm{~nm}$ laser ablation (LA) system coupled to an Agilent 7900 inductively coupled plasma mass spectrometer (ICPMS; trace elements). The error of the electron microprobe analyses is $<2 \%$, while that of the LA-ICP-MS analyses is $<10 \%$. Whole-rock analyses were undertaken at ALS Chemex 

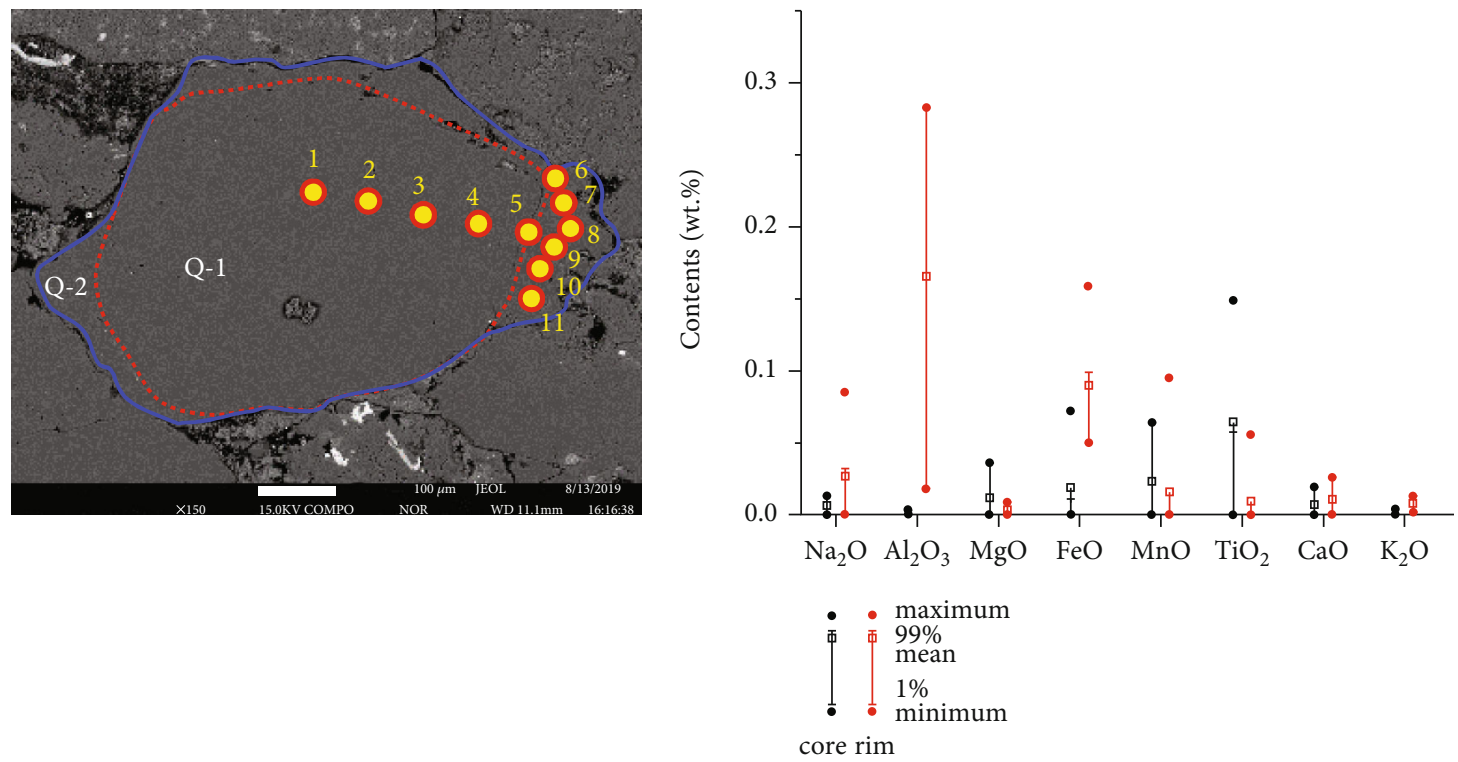

(a)
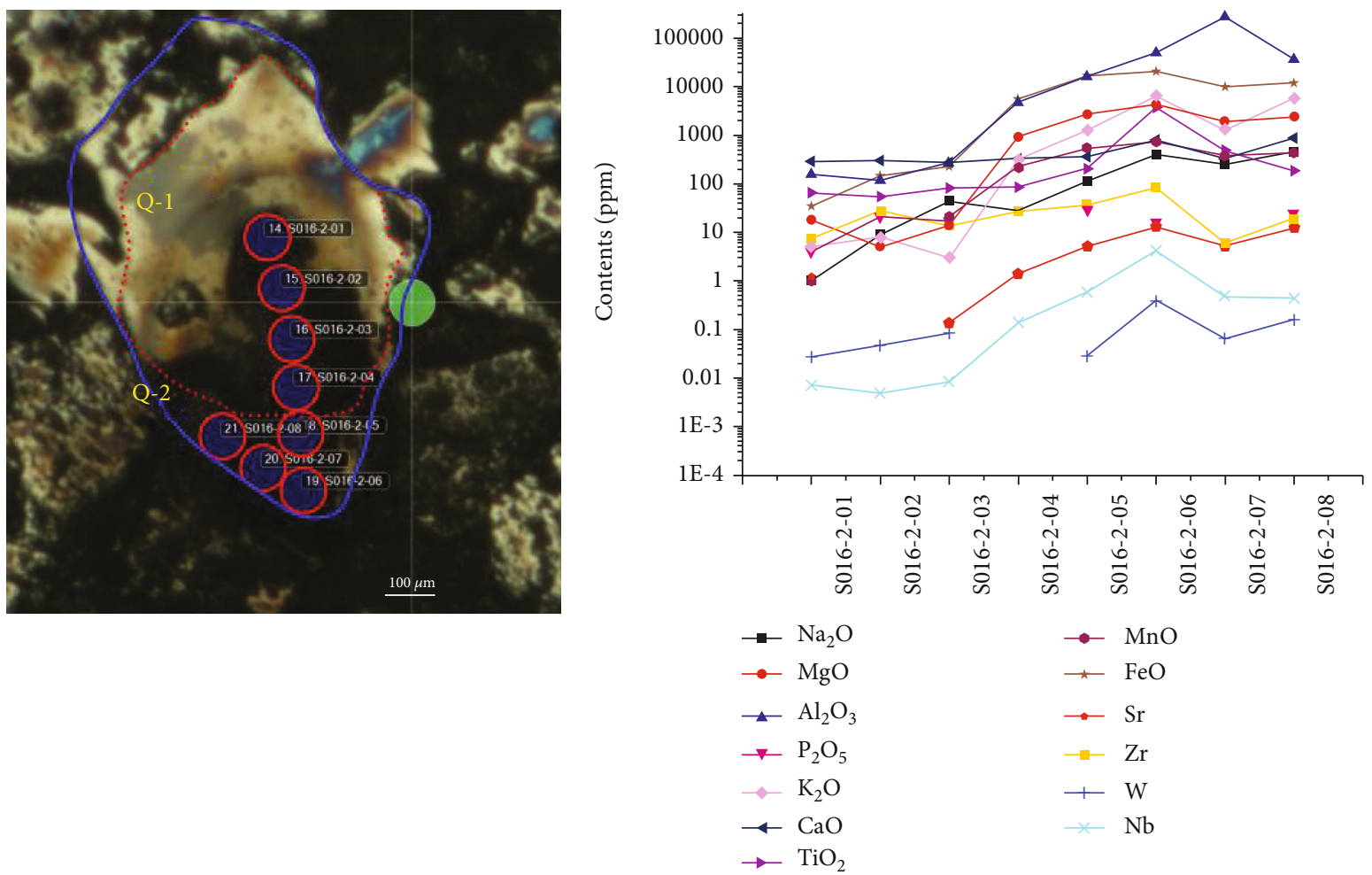

(c)

(d)

FIgURE 4: Distribution of electron microprobe analysis points (a) and major element contents (b) in quartz in a sample from well D13. (c, d) The distribution of LA-ICP-MS analysis points and major and trace element contents in quartz in the same sample (sample S016, $4209 \mathrm{~m}$ depth). Q-1 = core of the quartz grain; Q-2 = quartz overgrowth.

Company Ltd., Guangzhou, China, where major elements were determined by X-ray fluorescence (XRF) spectrometry with an error $<5 \%$ and trace elements were determined by ICP-MS with an error $<10 \%$. XRF mapping was conducted in the Key Laboratory of Deep Hydrocarbons, China University of Petroleum (East China), Qingdao, using a Bruker M4 Tornado instrument with a scanning spot size of $20 \mu \mathrm{m}$.

\section{Results}

4.1. Petrological Features of Quartz. The edges of quartz grains exhibit curved dissolution profiles under the microscope (Figure 2), and parts of the quartz edges are replaced or infilled with clay minerals. The surface of the quartz is relatively rough, and a large number of fluid inclusions 
TABLE 2: Major element data for quartz in the D13 well (in wt.\%).

\begin{tabular}{lcccccccccc}
\hline Point & $\mathrm{Na}_{2} \mathrm{O}$ & $\mathrm{Al}_{2} \mathrm{O}_{3}$ & $\mathrm{MgO}$ & $\mathrm{SiO}_{2}$ & $\mathrm{FeO}$ & $\mathrm{MnO}$ & $\mathrm{TiO}_{2}$ & $\mathrm{CaO}$ & $\mathrm{K} 2 \mathrm{O}$ & $\mathrm{Total}$ \\
\hline 1 & 0.002 & $\mathrm{bdl}$ & $\mathrm{bdl}$ & 98.98 & 0.011 & 0.006 & bdl & bdl & bdl & 99.00 \\
2 & 0.013 & bdl & bdl & 99.45 & 0.011 & bdl & 0.038 & 0.019 & 0.004 & 99.53 \\
3 & 0.011 & bdl & 0.023 & 99.29 & bdl & 0.064 & bdl & bdl & bdl & 99.39 \\
4 & 0.006 & bdl & bdl & 98.68 & bdl & bdl & 0.149 & 0.012 & bdl & 98.85 \\
5 & bdl & 0.003 & 0.036 & 99.74 & 0.072 & 0.045 & 0.038 & 0.004 & bdl & 99.94 \\
6 & 0.032 & 0.211 & bdl & 99.06 & 0.088 & bdl & 0.056 & 0.013 & 0.007 & 99.46 \\
7 & 0.015 & 0.246 & 0.009 & 98.03 & 0.066 & bdl & bdl & bdl & 0.004 & 98.37 \\
8 & 0.085 & 0.283 & 0.004 & 98.19 & 0.159 & 0.095 & bdl & 0.026 & 0.013 & 98.85 \\
9 & bdl & 0.2 & bdl & 98.15 & 0.05 & bdl & bdl & 0.015 & 0.009 & 98.42 \\
10 & bdl & 0.036 & 0.006 & 99.53 & 0.099 & bdl & bdl & 0.011 & 0.002 & 99.68 \\
11 & 0.027 & 0.018 & bdl & 99.03 & 0.077 & bdl & bdl & bdl & 0.005 & 99.16 \\
\hline
\end{tabular}

Note: bdl denotes below detection limit.

(typically $<10 \mu \mathrm{m}$ in size) are distributed along the fractures. Quartz overgrowths are developed along the edges of some grains. Most feldspar and lithic fragments in the sandy conglomerate have been altered, with the replacement products being mainly clay.

CL and SEM imaging was used to examine the interiors and edges of quartz grains. The quartz has obvious multiphase growth regions with different optical characteristics (Figures 3(a) and 3(b)). The secondary quartz is CL-dark and corresponds to quartz overgrowths. The quartz overgrowths are hexagonal and prism-shaped in SEM images (Figures 3(c) and 3(d)) and intergrown with clay minerals. Dissolution pores also occur near the edges of quartz grains.

4.2. In Situ Geochemistry of Quartz. Backscattered electron images also reveal the original quartz cores and overgrowths, and they are separated with dark and curved layers, similar to the results of petrological observations (Figures 4(a) and 4(b)). Major element contents were analyzed from the core to the rim in selected quartz grains. $\mathrm{SiO}_{2}$ contents are all $>98$ wt.\%. The distribution of the other major elements (Figures 4(a) and 4(b), Table 2) is variable, and most elements have significantly lower contents in the cores (Q-1) than in the overgrowths (Q-2), particularly for $\mathrm{Fe}$ and $\mathrm{Al}$.

LA-ICP-MS was also used to analyze the major and trace element contents. The core analyses (S016-2-01-04) have average $\mathrm{SiO}_{2}=98.94$ wt. $\%, \mathrm{Al}_{2} \mathrm{O}_{3}=0.133$ wt. $\%, \quad \mathrm{MnO}=$ 0.006 wt. $\%$, and $\mathrm{FeO}=0.148 \mathrm{wt} . \%$. The cores also have average $\mathrm{Co}=1.78 \mathrm{ppm}, \mathrm{Ni}=3.91 \mathrm{ppm}, \mathrm{Sr}=0.66 \mathrm{ppm}$, and $\mathrm{W}=$ $0.04 \mathrm{ppm}$. The average $\mathrm{SiO}_{2}, \mathrm{Al}_{2} \mathrm{O}_{3}, \mathrm{MnO}$, and $\mathrm{FeO}$ contents of the rims (S016-2-05-08) are 98.85, 3.261, 0.052, and 1.482 wt.\%, respectively. The rims have average $\mathrm{Co}=2.47$ ppm, $\mathrm{Ni}=25.92 \mathrm{ppm}, \mathrm{Sr}=8.98 \mathrm{ppm}$, and $\mathrm{W}=0.16 \mathrm{ppm}$. The cores and rims separated by a thin, dark, and clay layer exhibit the largest compositional differences (Figures 4(c) and 4(d), Table 3). Some trace (e.g., Sr and W) and major element (e.g., $\mathrm{Mn}, \mathrm{Fe}$, and $\mathrm{Al}$ ) contents are higher in the rims than in the cores. The differences can be by two or three orders of magnitude. However, some relatively immobile elements show no apparent concentration differences between the cores and rims (e.g., $\mathrm{Zr}$ ).
4.3. XRF Element Maps of Quartz. The elemental map showed that the distribution of elements in the rock thin sections is heterogeneous (Figure 5). Elements mobile in hydrothermal fluids, such as $\mathrm{Mn}$ and $\mathrm{Fe}$, are significantly concentrated at the edges of quartz grains.

4.4. Whole-Rock Geochemistry. Whole-rock geochemical data for 15 samples from 11 wells are listed in Table 4 . The samples have variable major element compositions, with $\mathrm{Si}$ $\mathrm{O}_{2}=57.92-78.98$ wt. \%, $\mathrm{MgO}=0.52-2.04$ wt. \%, $\mathrm{TFe}_{2} \mathrm{O}_{3}$ $=1.55-10.25$ wt. $\%, \mathrm{Al}_{2} \mathrm{O}_{3}=9.69-19.66$ wt. $\%, \mathrm{CaO}=0.25$ - 1.40 wt. $\%$, and $\mathrm{MnO}=0.05-0.20$ wt.\%. Total rare earth element (REE) concentrations vary from 81.50 to $140.85 \mathrm{ppm}$. The chondrite-normalized REE patterns of these samples show apparent fractionation of light REEs relative to heavy REEs (Figure $6(\mathrm{a})$ ), with $\mathrm{La}_{\mathrm{N}} / \mathrm{Yb}_{\mathrm{N}}=1.15-$ 9.03. The $\mathrm{Eu} / \mathrm{Eu} *$ values of the sandy conglomerates vary from 0.48 to 0.83 , reflecting negative Eu anomalies. In trace element patterns (Figure 6(b)), the large-ion lithophile elements (e.g., $\mathrm{Cs}, \mathrm{Rb}, \mathrm{K}$, and $\mathrm{Ba}$ ) exhibit variable contents. Some high-field-strength elements exhibit obvious negative anomalies, such as $\mathrm{Nb}$ and $\mathrm{Ta}$.

\section{Discussion}

5.1. Fluid-Rock Interactions Recorded by Quartz. Fluid-rock interactions occur widely in reservoirs, and these can cause migration of chemically active elements, dissolution of minerals, or modification of primary minerals $[34,59,60]$. The sandy conglomerates of the Baikouquan Formation exhibit dissolution and overgrowths at the edges of quartz grains, suggesting that these samples experienced strong fluid-rock interactions (Figures 2 and 3). The quartz grains developed numerous microcracks, and $\mathrm{SiO}_{2}$ from the hydrothermal fluids infilled these microcracks to form new quartz. In addition, abundant fluid inclusions were captured during this process. These samples exhibit obvious blue and white fluorescence around the quartz grains (Figure $7(\mathrm{a})$ ) and even some strong fluorescence at the edges of the grains (Figure 7(b)), implying that hydrocarbons migrated with the hydrothermal fluids involved in the fluid-rock interactions. 
TABle 3: In situ major and trace element data for quartz in the D13 well. Sample S016, $4209 \mathrm{~m}$ depth.

\begin{tabular}{|c|c|c|c|c|c|c|c|c|c|}
\hline Element & Unit & S016-2-01 & S016-2-02 & S016-2-03 & S016-2-04 & S016-2-05 & S016-2-06 & S016-2-07 & S016-2-08 \\
\hline $\mathrm{Na}_{2} \mathrm{O}$ & wt.\% & 0.0001 & 0.0009 & 0.0044 & 0.0028 & 0.0114 & 0.0403 & 0.0248 & 0.0456 \\
\hline $\mathrm{MgO}$ & wt.\% & 0.0018 & 0.0005 & 0.0014 & 0.0924 & 0.2689 & 0.4281 & 0.1951 & 0.238 \\
\hline $\mathrm{Al}_{2} \mathrm{O}_{3}$ & wt.\% & 0.0157 & 0.0117 & 0.027 & 0.4778 & 1.5872 & 5.0255 & 27.8972 & 3.6433 \\
\hline $\mathrm{SiO}_{2}$ & wt.\% & 98.8128 & 99.3119 & 99.1262 & 98.5171 & 99.5735 & 99.4796 & 97.9821 & 98.3665 \\
\hline $\mathrm{P}_{2} \mathrm{O}_{5}$ & wt.\% & 0.0004 & 0.0021 & 0.0017 & bdl & 0.0029 & 0.0016 & bdl & 0.0025 \\
\hline $\mathrm{K}_{2} \mathrm{O}$ & wt.\% & 0.0005 & 0.0008 & 0.0003 & 0.0315 & 0.1263 & 0.6335 & 0.1276 & 0.5843 \\
\hline $\mathrm{CaO}$ & wt.\% & 0.0052 & 0.0023 & 0.0089 & 0.0106 & 0.0128 & 0.0484 & 0.0331 & 0.0502 \\
\hline $\mathrm{CaO}$ & wt.\% & 0.0286 & 0.0299 & 0.0275 & 0.0337 & 0.0359 & 0.0803 & 0.0321 & 0.0873 \\
\hline $\mathrm{TiO}_{2}$ & wt.\% & 0.0065 & 0.0054 & 0.0081 & 0.0085 & 0.0206 & 0.3722 & 0.0481 & 0.0186 \\
\hline $\mathrm{MnO}$ & wt.\% & 0.0001 & bdl & 0.0021 & 0.0219 & 0.0542 & 0.0746 & 0.0376 & 0.0429 \\
\hline $\mathrm{FeO}$ & wt.\% & 0.0035 & 0.0146 & 0.0227 & 0.5517 & 1.6852 & 2.0688 & 0.9899 & 1.1847 \\
\hline $\mathrm{Li}$ & ppm & 2.0965 & bdl & 3.1423 & 7.8239 & 16.3127 & 23.3518 & 47.5405 & 47.7116 \\
\hline $\mathrm{Be}$ & ppm & bdl & 0.0059 & 0.0268 & 0.1594 & 0.1286 & 0.5496 & 0.2767 & 0.5168 \\
\hline B & ppm & 0.3452 & 0.9822 & 1.7401 & 0.3358 & 3.3413 & 15.6646 & 2.9438 & 5.3068 \\
\hline Sc & ppm & 1.5332 & 1.5815 & 1.7752 & 2.4409 & 2.8277 & 5.2015 & 4.5676 & 3.5416 \\
\hline $\mathrm{V}$ & ppm & 0.0768 & 0.141 & 0.1456 & 6.2744 & 18.6091 & 38.5048 & 44.2837 & 20.8029 \\
\hline $\mathrm{Cr}$ & ppm & 0.9691 & 0.8712 & 1.1591 & 2.8601 & 5.3181 & 8.6423 & 8.2257 & 4.4051 \\
\hline Co & ppm & 0.0849 & 3.4376 & 2.4933 & 1.1143 & 2.4508 & 3.1264 & 2.5711 & 1.737 \\
\hline $\mathrm{Ni}$ & ppm & 0.1548 & 0.446 & bdl & 15.0496 & 18.0809 & 16.3241 & 60.7456 & 8.5679 \\
\hline $\mathrm{Cu}$ & ppm & 4.6485 & 1.583 & 0.4035 & 10.0872 & 3.4157 & 8.3014 & 15.9753 & 10.3209 \\
\hline $\mathrm{Zn}$ & ppm & 4.53 & 7.0383 & 3.4491 & 10.9982 & 15.4474 & 20.3231 & 8.3061 & 250.1787 \\
\hline $\mathrm{Ga}$ & ppm & 0.0236 & 0.0091 & 0.0352 & 0.7123 & 2.3717 & 4.8447 & 5.7437 & 3.5102 \\
\hline $\mathrm{Ge}$ & ppm & 1.1098 & 1.0578 & 0.917 & 1.2367 & 1.2775 & 1.584 & 1.1088 & 1.2653 \\
\hline $\mathrm{Rb}$ & ppm & 0.0121 & 0.1982 & bdl & 0.7515 & 2.4961 & 21.3532 & 2.597 & 15.8376 \\
\hline $\mathrm{Sr}$ & ppm & 1.1306 & bdl & 0.1347 & 1.3932 & 5.1935 & 13.4053 & 5.3072 & 12.018 \\
\hline $\mathrm{Y}$ & ppm & 0.0789 & bdl & 0.3099 & 3.7087 & 4.4541 & 8.788 & 0.6344 & 3.0661 \\
\hline $\mathrm{Zr}$ & ppm & 7.4731 & 27.9566 & 13.5468 & 27.0276 & 36.3953 & 83.4228 & 6.0641 & 19.4439 \\
\hline $\mathrm{Nb}$ & ppm & 0.0072 & 0.0048 & 0.0083 & 0.1382 & 0.5832 & 4.2074 & 0.483 & 0.4359 \\
\hline Mo & ppm & 0.0139 & 3.3567 & 0.8704 & bdl & 0.3764 & 0.1611 & 0.025 & 0.0231 \\
\hline Cs & ppm & 0.0247 & 0.0419 & 0.146 & 0.0547 & 0.2173 & 1.947 & 0.1248 & 0.4007 \\
\hline $\mathrm{Ba}$ & ppm & 0.0359 & 0.0357 & 1.0805 & 5.7055 & 20.774 & 92.4082 & 16.6073 & 125.0756 \\
\hline $\mathrm{La}$ & ppm & 0.0032 & bdl & 0.0037 & 0.0462 & 0.2222 & 1.2463 & 0.3332 & 7.1036 \\
\hline $\mathrm{Ce}$ & ppm & 0.1066 & 0.003 & 0.0191 & 0.1468 & 0.6328 & 1.9927 & 1.2214 & 12.4724 \\
\hline $\operatorname{Pr}$ & ppm & 0.0059 & 0.0093 & bdl & 0.0183 & 0.079 & 0.1865 & 0.0786 & 1.1895 \\
\hline $\mathrm{Nd}$ & ppm & 0.0064 & 0.0191 & 0.0074 & 0.107 & 0.4143 & 0.7609 & 0.2295 & 3.6637 \\
\hline $\mathrm{Sm}$ & ppm & bdl & bdl & 0.0168 & 0.0664 & 0.2537 & 0.3327 & 0.045 & 0.4885 \\
\hline $\mathrm{Eu}$ & ppm & 0.0185 & 0.0593 & 0.0309 & 0.0137 & 0.0202 & 0.1079 & 0.0064 & 0.1828 \\
\hline $\mathrm{Gd}$ & ppm & bdl & bdl & 0.0078 & 0.1565 & 0.3665 & 0.4613 & 0.0312 & 0.3494 \\
\hline $\mathrm{Tb}$ & ppm & bdl & bdl & 0.0038 & 0.0543 & 0.1052 & 0.2078 & 0.0237 & 0.0699 \\
\hline Dy & ppm & bdl & 0.0307 & bdl & 0.6531 & 0.746 & 1.4292 & 0.1024 & 0.4987 \\
\hline Ho & ppm & bdl & 0.0085 & 0.0136 & 0.1708 & 0.157 & 0.3226 & 0.0166 & 0.1081 \\
\hline Er & ppm & 0.0164 & 0.418 & 0.0189 & 0.3973 & 0.4846 & 0.8769 & 0.0594 & 0.2808 \\
\hline $\mathrm{Tm}$ & ppm & 0.0049 & bdl & 0.0056 & 0.1347 & 0.0878 & 0.1604 & 0.0075 & 0.046 \\
\hline $\mathrm{Yb}$ & ppm & 0.0041 & 0.0041 & 0.0048 & 0.4731 & 0.493 & 1.0755 & 0.0836 & 0.3126 \\
\hline $\mathrm{Lu}$ & ppm & 0.001 & 0.001 & 0.007 & 0.0804 & 0.0829 & 0.15 & 0.0078 & 0.0509 \\
\hline Hf & ppm & bdl & bdl & 0.0036 & 0.6129 & 0.8206 & 2.2239 & 0.195 & 0.5997 \\
\hline $\mathrm{Ta}$ & ppm & 0.0032 & bdl & bdl & 0.0082 & 0.0538 & 0.4038 & 0.1343 & 0.0415 \\
\hline W & ppm & 0.0274 & 0.0471 & 0.0823 & bdl & 0.029 & 0.4034 & 0.0648 & 0.1617 \\
\hline $\mathrm{Hg}$ & ppm & bdl & bdl & bdl & bdl & bdl & bdl & bdl & bdl \\
\hline $\mathrm{Tl}$ & ppm & 0.6772 & bdl & 0.0362 & bdl & 0.0633 & 0.0847 & 0.0332 & 0.0451 \\
\hline $\mathrm{Pb}$ & ppm & 6.8722 & 0.4472 & 1.3452 & 0.0906 & 0.3238 & 3.8856 & 0.7726 & 0.4805 \\
\hline Th & ppm & 0.0192 & bdl & 0.0225 & 2.0437 & 1.3406 & 9.2599 & 0.8271 & 8.162 \\
\hline $\mathrm{U}$ & ppm & 0.0017 & 0.0051 & 0.0778 & 0.2246 & 0.2462 & 0.9181 & 0.165 & 0.8694 \\
\hline
\end{tabular}

Note: bdl denotes below detection limit. 


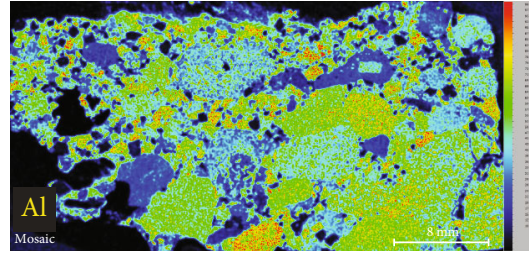

(a)

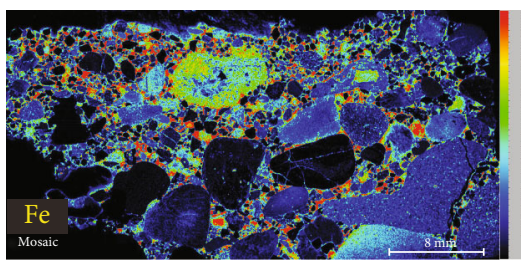

(c)

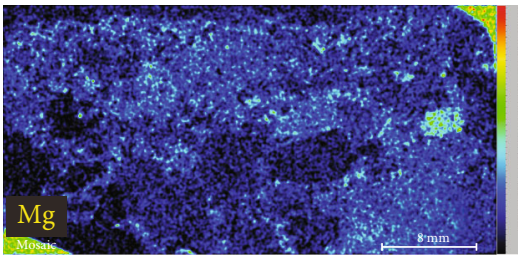

(e)

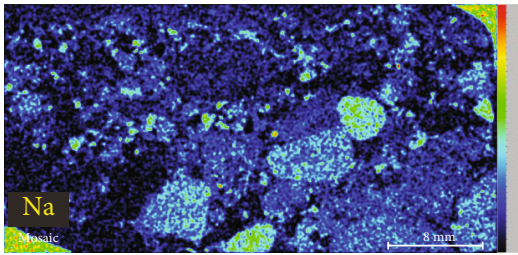

(g)

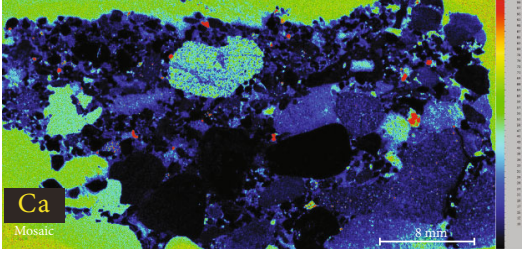

(b)

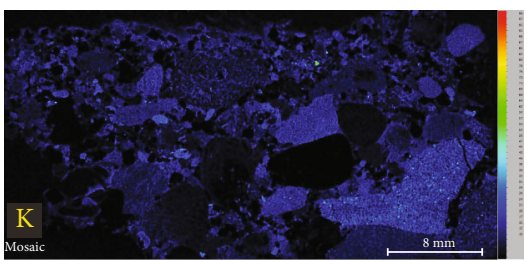

(d)

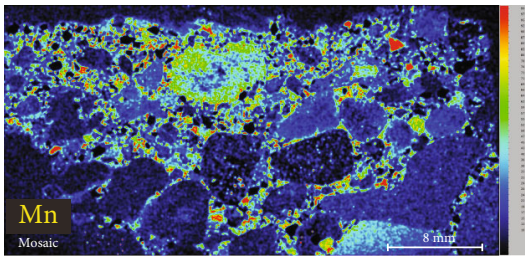

(f)

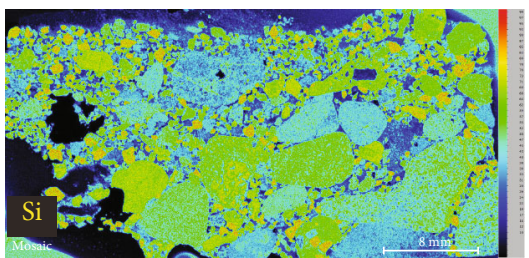

(h)

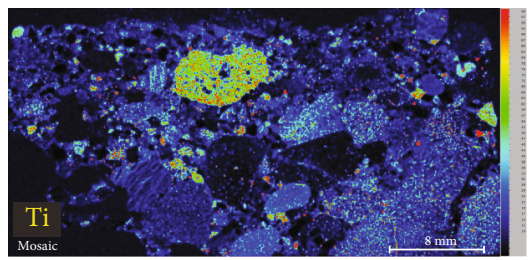

(i)

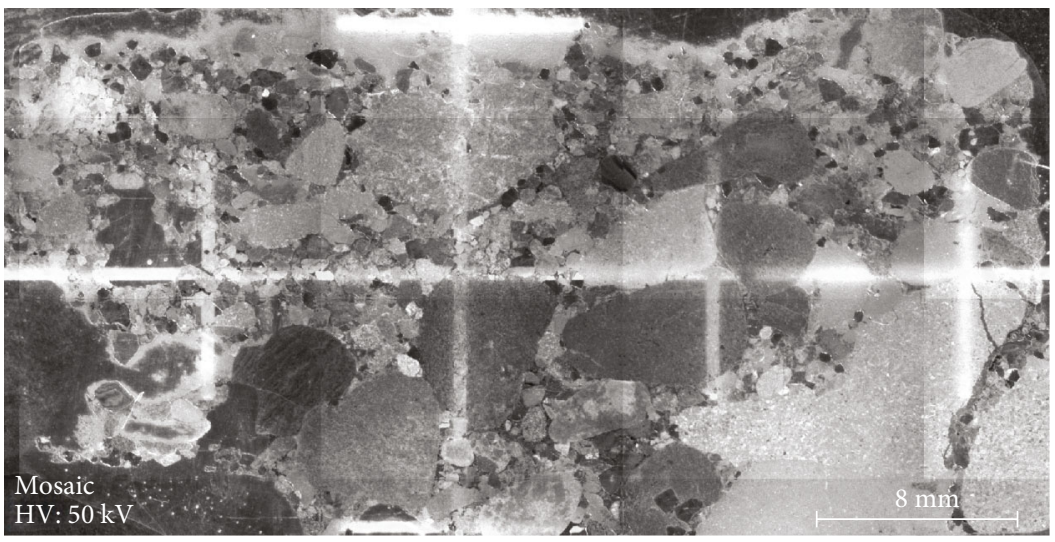

(j)

FIGURE 5: Element maps of a sample from well D5 obtained by XRF analysis. On the migration pathway, Al, Fe, Mn, and Ti are enriched and have been affected by migration, indicative of strong fluid-rock interactions. Q-1 = core of the quartz grain; Q-2= quartz overgrowth.

The geochemical data indicate that the chemically active elements, such as $\mathrm{Fe}, \mathrm{Mn}, \mathrm{Al}, \mathrm{Sr}$, and $\mathrm{W}$, have higher contents in the rims than in the cores of quartz (Figures 4 and 5), implying that these elements migrated with the fluids and were deposited in the overgrowths.

The elemental contents of the quartz overgrowths in the reservoirs of the Baikouquan Formation in the Mahu Sag depend on internal and external factors. The internal factors pertain mainly to the initial elemental abundances of the quartz; the external factors pertain mainly to the mobility of elements during fluid migration and fluid-rock interactions. Major elements such as $\mathrm{Mn}, \mathrm{Fe}$, and $\mathrm{Al}$ and trace elements such as $\mathrm{Sr}$ and $\mathrm{W}$ in the quartz cores are relatively low in content. Permian source rocks in the study area are rich in $\mathrm{Mn}, \mathrm{Fe}$, and $\mathrm{Cr}$ [61]. Insoluble $\mathrm{MnO}_{2}$ can react with water in the presence of anaerobic bacteria to form $\mathrm{Mn}^{2+}$ 
TABLE 4: Whole-rock major (in wt.\%) and trace element (in ppm) data for samples from the Baikouquan Formation.

\begin{tabular}{|c|c|c|c|c|c|c|c|c|c|c|c|c|c|c|c|}
\hline Well & B63 & B63 & B25 & YB2 & $\mathrm{AH} 2$ & AH11 & D15 & D15 & D12 & D12 & D12 & D18 & D13 & MH23 & MA18 \\
\hline Depth (m) & 2514 & 2452 & 2318 & 4110 & 3314 & 2825 & 4245 & 4254 & 4269 & 4267 & 4284 & 4451 & 4209 & 4079 & 3906 \\
\hline $\mathrm{Al}_{2} \mathrm{O}_{3}$ & 19.66 & 17.44 & 13.12 & 14.9 & 9.69 & 13.15 & 10.83 & 12.42 & 10.62 & 11.29 & 10.65 & 12.78 & 11.04 & 11.1 & 13.46 \\
\hline $\mathrm{BaO}$ & 0.03 & 0.06 & 0.06 & 0.03 & 0.01 & 0.04 & 0.02 & 0.01 & 0.01 & 0.01 & 0.01 & 0.02 & 0.01 & 0.02 & 0.02 \\
\hline $\mathrm{CaO}$ & 0.64 & 0.66 & 0.59 & 0.47 & 0.48 & 0.4 & 0.64 & 0.55 & 0.25 & 0.42 & 0.4 & 1.04 & 1.4 & 0.38 & 1.3 \\
\hline $\mathrm{Cr}_{2} \mathrm{O}_{3}$ & 0.02 & 0.05 & 0.03 & $<0.01$ & 0.03 & 0.02 & 0.02 & 0.02 & 0.01 & 0.03 & $<0.01$ & $<0.01$ & $<0.01$ & $<0.01$ & 0.01 \\
\hline $\mathrm{TFe}_{2} \mathrm{O}_{3}$ & 8.94 & 10.25 & 4.33 & 1.68 & 2.19 & 3.12 & 2.78 & 3.99 & 4.16 & 3.84 & 2.66 & 4.45 & 3.45 & 1.55 & 3.73 \\
\hline $\mathrm{K}_{2} \mathrm{O}$ & 3.2 & 2.73 & 2.39 & 2.4 & 1.31 & 2.16 & 1.16 & 1.37 & 1.01 & 1 & 1.39 & 1.09 & 0.92 & 1.48 & 1.44 \\
\hline $\mathrm{MgO}$ & 0.95 & 2.04 & 1.3 & 0.66 & 0.75 & 0.9 & 0.76 & 0.73 & 0.88 & 0.9 & 0.62 & 1.33 & 0.97 & 0.52 & 1 \\
\hline $\mathrm{MnO}$ & 0.08 & 0.11 & 0.09 & 0.05 & 0.06 & 0.06 & 0.07 & 0.09 & 0.15 & 0.13 & 0.08 & 0.18 & 0.16 & 0.08 & 0.2 \\
\hline $\mathrm{Na}_{2} \mathrm{O}$ & 1.23 & 1.33 & 2.85 & 2.4 & 2.95 & 3.83 & 3.05 & 3.3 & 2.68 & 2.99 & 2.61 & 3.12 & 2.96 & 2.75 & 3.84 \\
\hline $\mathrm{P}_{2} \mathrm{O}_{5}$ & 0.01 & 0.03 & 0.16 & 0.05 & 0.07 & 0.11 & 0.15 & 0.13 & 0.03 & 0.16 & 0.1 & 0.2 & 0.15 & 0.07 & 0.14 \\
\hline $\mathrm{SiO}_{2}$ & 57.92 & 58.04 & 70.95 & 72.4 & 78.91 & 73.28 & 77.35 & 73.81 & 77.68 & 76.59 & 78.93 & 70.36 & 75.04 & 78.98 & 70.47 \\
\hline $\mathrm{SO}_{3}$ & $<0.01$ & 0.02 & 0.02 & 0.02 & $<0.01$ & $<0.01$ & $<0.01$ & $<0.01$ & $<0.01$ & 0.01 & $<0.01$ & $<0.01$ & 0.01 & $<0.01$ & 0.01 \\
\hline $\mathrm{SrO}$ & 0.01 & 0.01 & 0.02 & 0.01 & 0.01 & 0.01 & 0.01 & 0.01 & 0.01 & 0.01 & 0.01 & 0.01 & 0.01 & 0.01 & 0.02 \\
\hline $\mathrm{TiO}_{2}$ & 0.91 & 0.82 & 0.66 & 0.63 & 0.39 & 0.48 & 0.43 & 0.48 & 0.37 & 0.47 & 0.37 & 0.78 & 0.48 & 0.19 & 0.44 \\
\hline LOI & 6.14 & 6.36 & 2.92 & 3.37 & 2.49 & 2.04 & 2.37 & 2.6 & 1.95 & 2.17 & 1.9 & 3.97 & 3.53 & 2.26 & 3.56 \\
\hline $\mathrm{La}$ & 12.7 & 19.7 & 15.2 & 23.3 & 14.9 & 17.6 & 24 & 27.9 & 15.9 & 23.1 & 20.3 & 21.7 & 17.8 & 18.6 & 20.1 \\
\hline $\mathrm{Ce}$ & 23.7 & 43.2 & 32.7 & 51 & 34.8 & 37.7 & 53.1 & 55.3 & 34.3 & 50.6 & 41.7 & 48.1 & 38 & 33.7 & 48.9 \\
\hline $\operatorname{Pr}$ & 2.68 & 5.16 & 4.28 & 5.75 & 4.41 & 4.53 & 6.52 & 6.13 & 3.89 & 5.92 & 5.06 & 5.72 & 4.44 & 3.65 & 6.03 \\
\hline $\mathrm{Nd}$ & 10.1 & 20.4 & 17.5 & 20.4 & 17.6 & 17.6 & 26.1 & 24.1 & 14.7 & 23 & 19.2 & 21.6 & 18.6 & 13.9 & 25.5 \\
\hline $\mathrm{Sm}$ & 2.81 & 4.82 & 4.02 & 4.28 & 4.02 & 3.82 & 5.98 & 5.65 & 2.99 & 5 & 4.59 & 4.98 & 4.16 & 2.97 & 5.52 \\
\hline $\mathrm{Eu}$ & 0.58 & 1.02 & 0.97 & 0.75 & 0.86 & 0.97 & 1.09 & 0.95 & 0.56 & 1.04 & 0.79 & 1.01 & 0.86 & 0.46 & 1.24 \\
\hline $\mathrm{Gd}$ & 4.84 & 4.79 & 3.98 & 3.87 & 3.35 & 3.31 & 5.42 & 4.86 & 2.59 & 4.72 & 4.18 & 4.58 & 3.71 & 2.2 & 4.75 \\
\hline $\mathrm{Tb}$ & 1.26 & 0.88 & 0.7 & 0.8 & 0.54 & 0.53 & 0.95 & 0.86 & 0.47 & 0.79 & 0.7 & 0.76 & 0.59 & 0.35 & 0.72 \\
\hline Dy & 9.43 & 5.57 & 4.37 & 5.38 & 3.14 & 3.24 & 5.47 & 5.47 & 3.04 & 4.85 & 4.14 & 4.51 & 3.76 & 2.12 & 4.24 \\
\hline Ho & 2.29 & 1.25 & 0.96 & 1.25 & 0.66 & 0.72 & 1.16 & 1.23 & 0.69 & 1.06 & 0.92 & 0.97 & 0.84 & 0.45 & 0.89 \\
\hline $\mathrm{Er}$ & 7.28 & 3.65 & 2.76 & 3.84 & 1.74 & 2.15 & 3.37 & 3.58 & 2.09 & 3.18 & 2.76 & 2.85 & 2.43 & 1.26 & 2.48 \\
\hline $\mathrm{Tm}$ & 1.14 & 0.56 & 0.42 & 0.63 & 0.25 & 0.35 & 0.52 & 0.56 & 0.33 & 0.48 & 0.42 & 0.44 & 0.39 & 0.2 & 0.38 \\
\hline $\mathrm{Yb}$ & 7.52 & 3.68 & 2.81 & 4.37 & 1.73 & 2.47 & 3.55 & 3.68 & 2.29 & 3.29 & 2.84 & 2.87 & 2.57 & 1.4 & 2.51 \\
\hline $\mathrm{Lu}$ & 1.22 & 0.6 & 0.48 & 0.7 & 0.3 & 0.4 & 0.56 & 0.58 & 0.38 & 0.54 & 0.46 & 0.46 & 0.43 & 0.24 & 0.4 \\
\hline $\mathrm{Y}$ & 65.7 & 35.3 & 25.1 & 33.1 & 17.2 & 19.6 & 32.4 & 32.6 & 19.8 & 29.1 & 25.3 & 26.6 & 24.4 & 13.2 & 24.9 \\
\hline Cs & 11.35 & 7.47 & 1.07 & 2.31 & 0.68 & 0.87 & 0.87 & 1.09 & 0.9 & 0.97 & 1.02 & 1.24 & 0.88 & 0.44 & 0.81 \\
\hline $\mathrm{Rb}$ & 101 & 83.1 & 54.5 & 64.3 & 33.1 & 49.3 & 32.4 & 37.7 & 27.7 & 29.4 & 38.2 & 30.4 & 25.1 & 31.4 & 34.7 \\
\hline $\mathrm{Ba}$ & 392 & 612 & 724 & 390 & 263 & 521 & 293 & 253 & 186.5 & 200 & 235 & 245 & 187 & 290 & 283 \\
\hline Th & 11.3 & 6.6 & 4.25 & 8.46 & 2.78 & 4 & 6.34 & 6.83 & 5.08 & 6.51 & 5.99 & 5.68 & 5.68 & 3.71 & 3.97 \\
\hline $\mathrm{U}$ & 2.57 & 2.04 & 1.65 & 2.82 & 1.19 & 1.34 & 2.06 & 2.24 & 1.67 & 2.04 & 1.99 & 1.68 & 1.62 & 1.09 & 1.4 \\
\hline $\mathrm{Nb}$ & 13.3 & 9.7 & 6 & 13.4 & 5 & 4.9 & 9.2 & 10.2 & 7.9 & 8.9 & 8.9 & 9.8 & 8 & 4.2 & 5 \\
\hline $\mathrm{Ta}$ & 0.8 & 0.6 & 0.3 & 0.9 & 0.3 & 0.3 & 0.5 & 0.6 & 0.4 & 0.6 & 0.6 & 0.6 & 0.4 & 0.3 & 0.3 \\
\hline $\mathrm{Cr}$ & 120 & 210 & 130 & 20 & 240 & 140 & 10 & 30 & 10 & 10 & 20 & 40 & 40 & 30 & 80 \\
\hline $\mathrm{Ga}$ & 23.2 & 19.6 & 14.5 & 17.5 & 10.3 & 14.4 & 12.3 & 15.4 & 11.8 & 13.2 & 12.9 & 13.8 & 10.3 & 13.8 & 14.4 \\
\hline $\mathrm{Hf}$ & 14.8 & 5.8 & 4.4 & 7.3 & 6 & 4.3 & 5.3 & 6.2 & 4.4 & 5.7 & 4.9 & 5 & 4.4 & 3 & 3.8 \\
\hline $\mathrm{Sr}$ & 67.9 & 112 & 201 & 140 & 94.4 & 168.5 & 130.5 & 130.5 & 89 & 98.1 & 95.9 & 133.5 & 124.5 & 96.3 & 187 \\
\hline $\mathrm{V}$ & 79 & 103 & 80 & 73 & 73 & 61 & 60 & 51 & 62 & 73 & 51 & 104 & 65 & 37 & 64 \\
\hline $\mathrm{Zr}$ & 641 & 224 & 163 & 279 & 258 & 154 & 211 & 238 & 170 & 217 & 197 & 208 & 170 & 108 & 143 \\
\hline $\mathrm{MnO} / \mathrm{Zr}$ & 1.25 & 4.91 & 5.52 & 1.79 & 2.33 & 3.9 & 3.32 & 3.78 & 8.82 & 5.99 & 4.06 & 8.65 & 9.41 & 7.41 & 13.99 \\
\hline $\mathrm{Y} / \mathrm{Ho}$ & 28.69 & 28.24 & 26.15 & 26.48 & 26.06 & 27.22 & 27.93 & 26.5 & 28.7 & 27.45 & 27.5 & 27.42 & 29.05 & 29.33 & 27.98 \\
\hline $\mathrm{La}_{\mathrm{N}} / \mathrm{Yb}_{\mathrm{N}}$ & 1.15 & 3.64 & 3.67 & 3.62 & 5.85 & 4.84 & 4.59 & 5.15 & 4.72 & 4.77 & 4.86 & 5.14 & 4.71 & 9.03 & 5.44 \\
\hline$\delta \mathrm{Eu}$ & 0.48 & 0.65 & 0.74 & 0.56 & 0.71 & 0.83 & 0.58 & 0.55 & 0.61 & 0.65 & 0.55 & 0.64 & 0.67 & 0.55 & 0.74 \\
\hline$\Sigma \mathrm{REE}$ & 87.55 & 115.3 & 91.15 & 126.3 & 88.3 & 95.39 & 137.8 & 140.9 & 84.22 & 127.6 & 108.1 & 120.6 & 98.58 & 81.5 & 123.7 \\
\hline
\end{tabular}




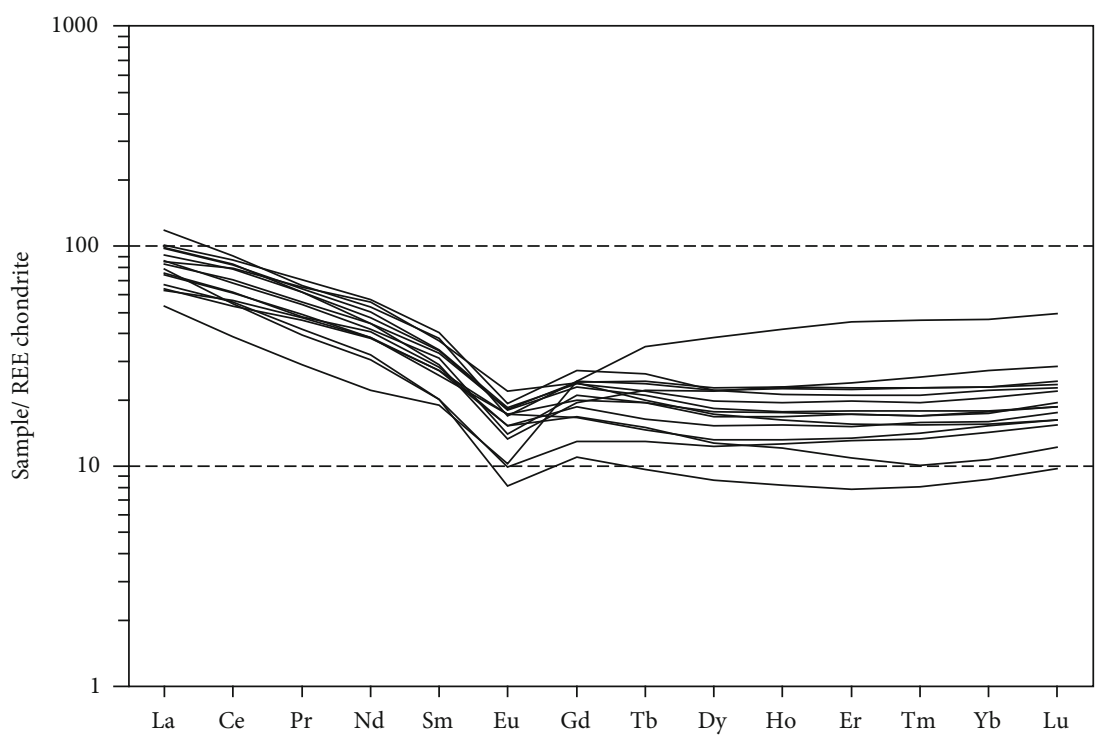

(a)

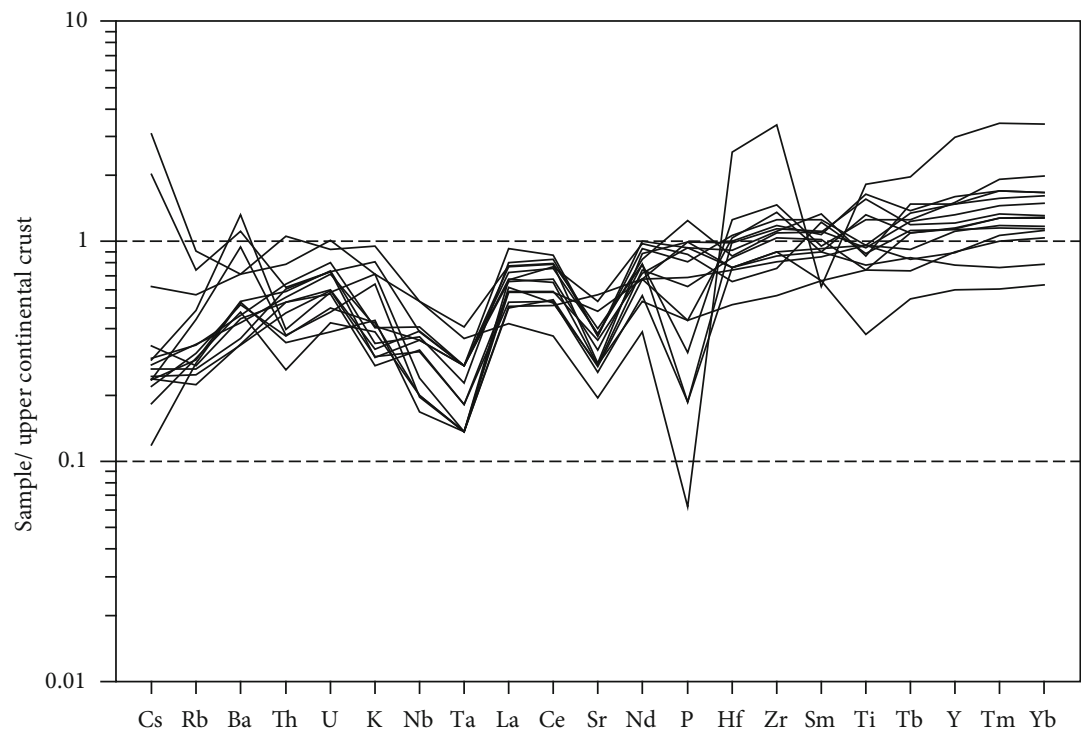

(b)

Figure 6: (a) Chondrite-normalized REE and (b) incompatible trace element patterns for sandy conglomerate samples in the Mahu Sag. Chondrite values are from [78]. Upper continental crust values are from [79].

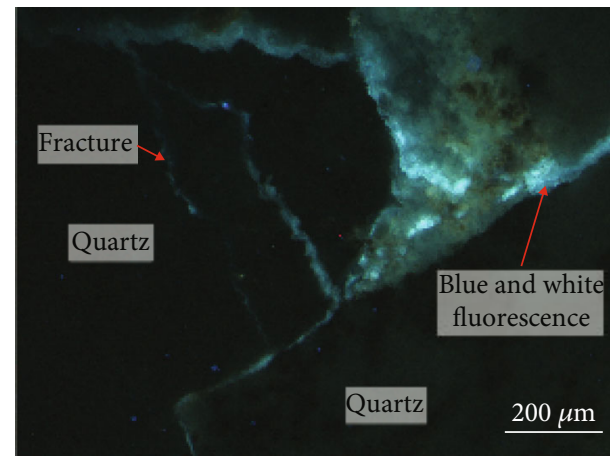

Ma 18, T1b, 3870.2m, sandy conglomerate

(a)

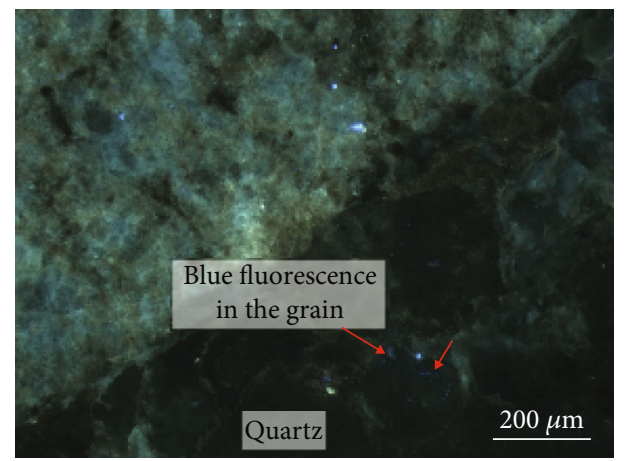

AH 2, T1b, 3286.9m, sandy conglomerate

(b)

FIGURE 7: Fluorescence microscopy photographs showing the oil migration pathways in the Baikouquan Formation. 


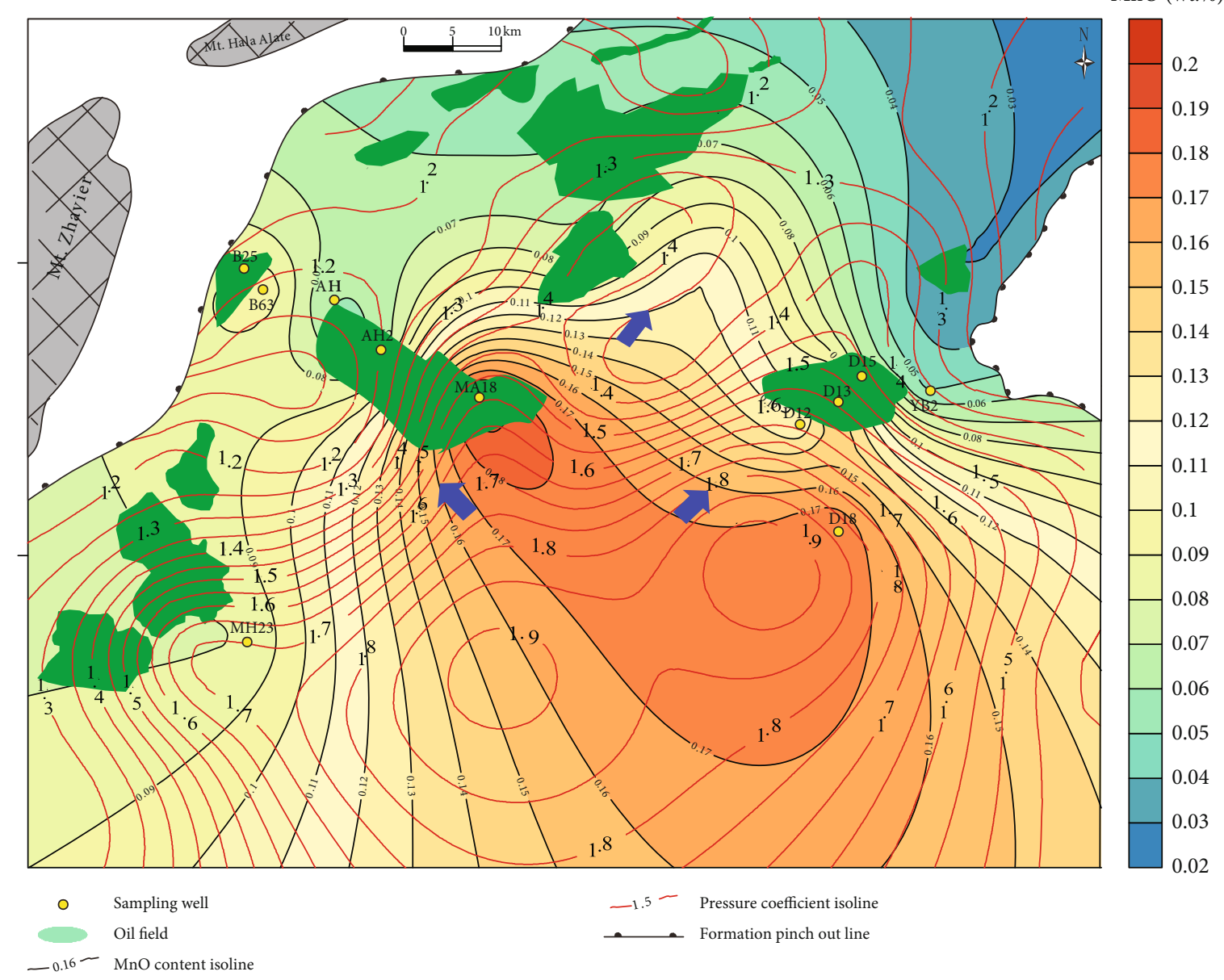

(a)

Figure 8: Continued. 
Sr (ppm)

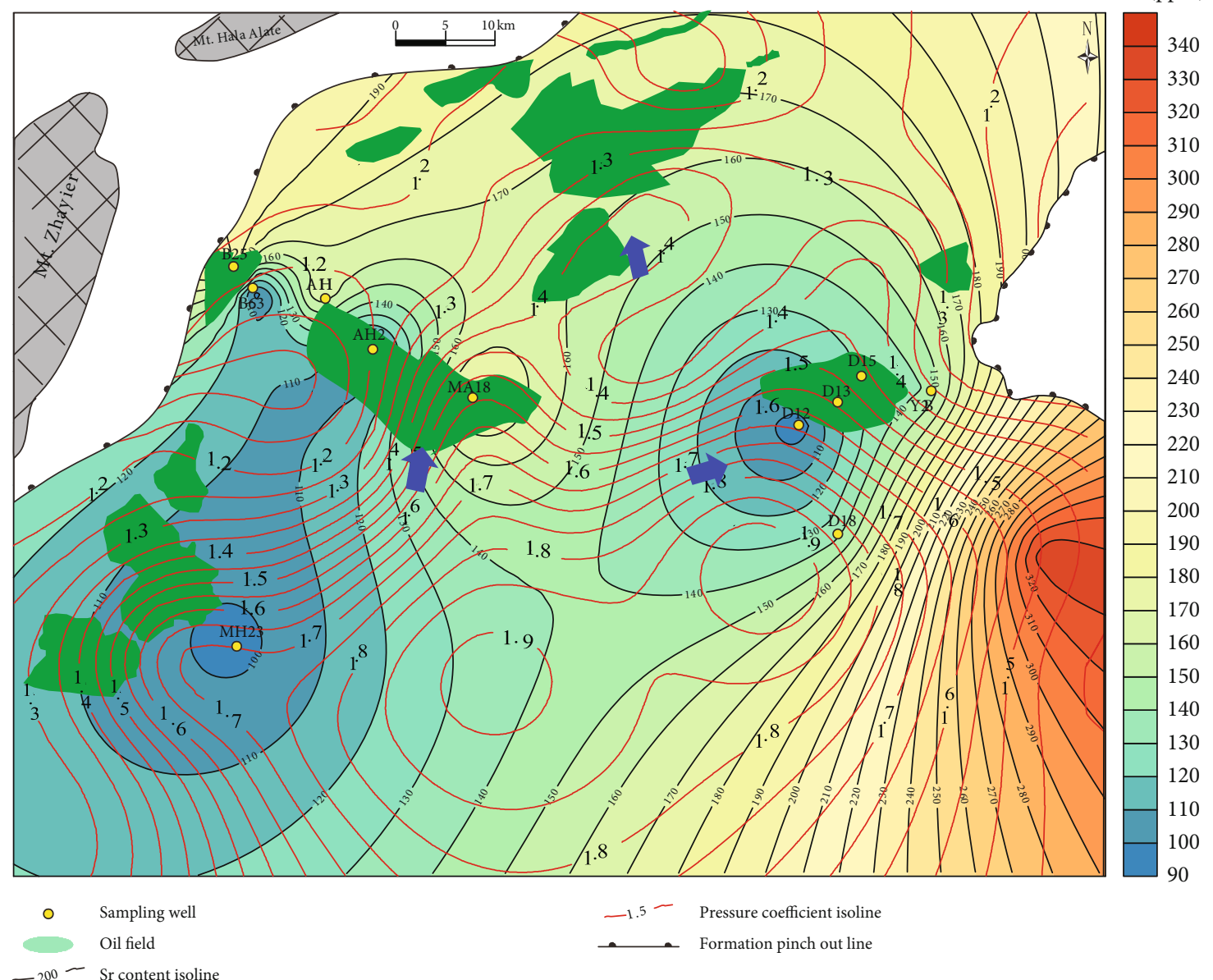

(b)

FIgURE 8: Continued. 


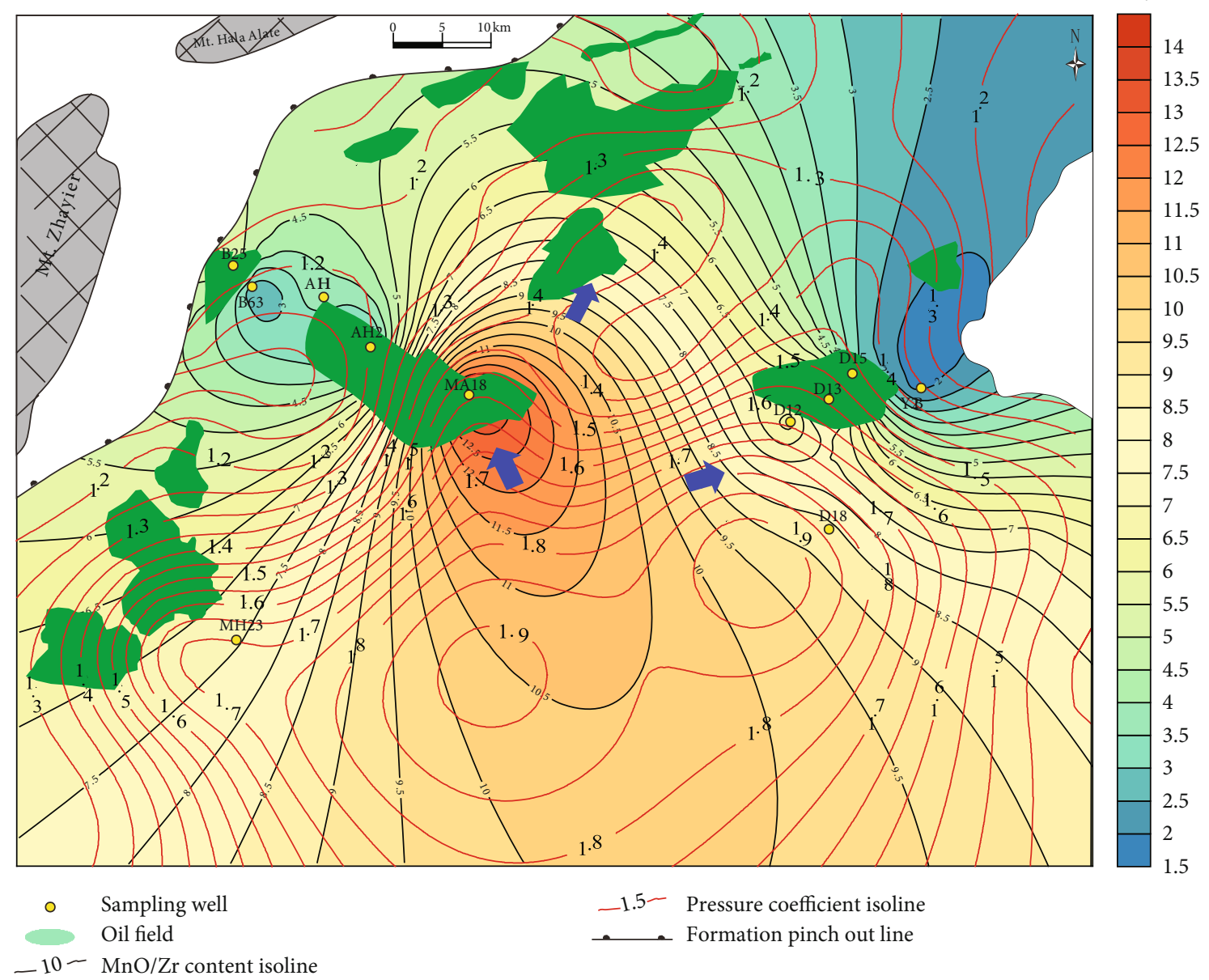

(c)

Figure 8: Continued. 


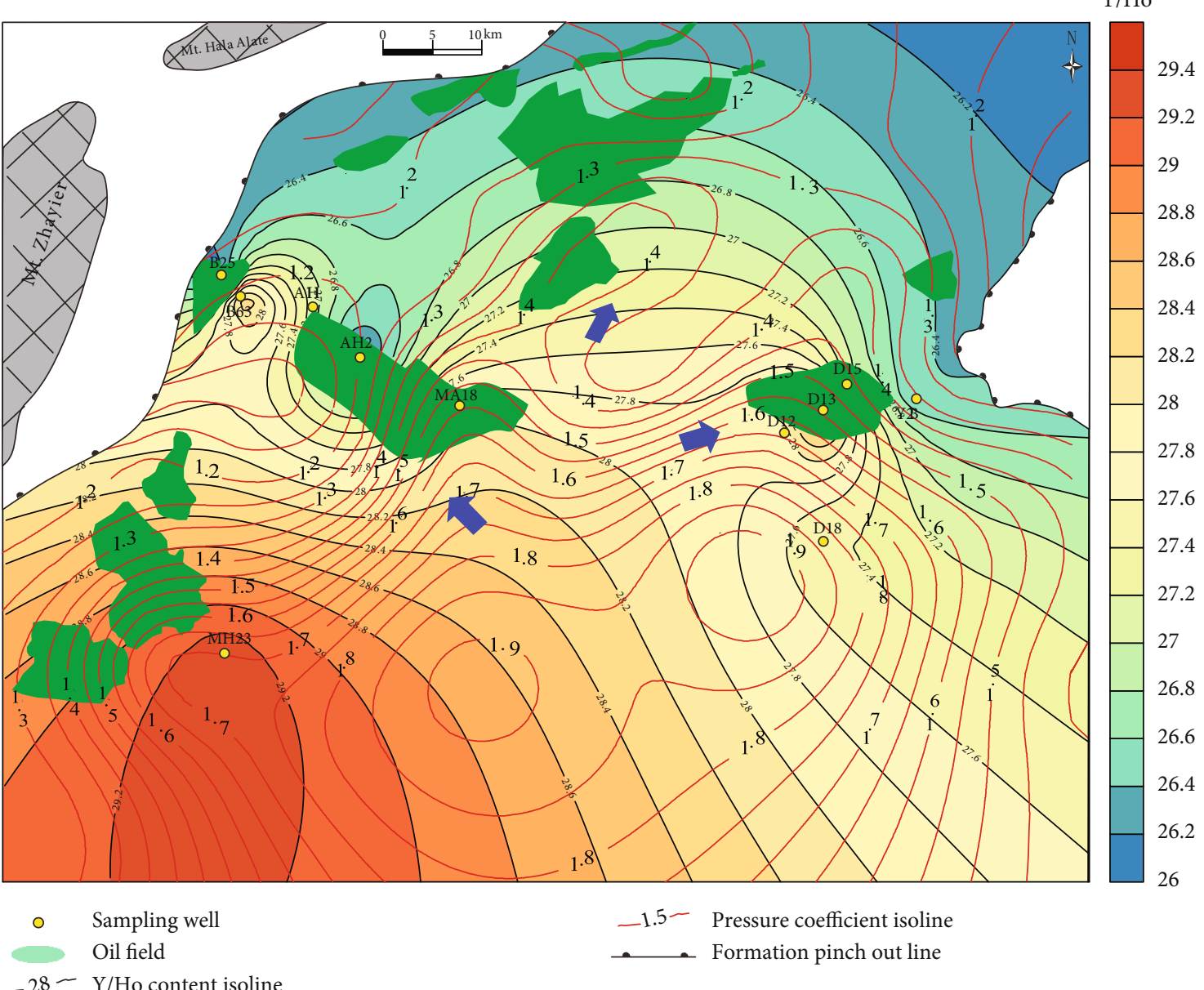

(d)

Figure 8: (a) Contour map of MnO contents (wt.\%) and pressure coefficients around the Mahu Sag. (b) Contour map of Sr contents (ppm) and pressure coefficients around the Mahu Sag. (c) Contour map of MnO/Zr ratios and pressure coefficients around the Mahu Sag. (d) Contour map of $\mathrm{Y} / \mathrm{Ho}$ ratios and pressure coefficients around the Mahu Sag.

and $\mathrm{OH}^{-}$, which allows $\mathrm{Mn}$ to be dissolved in hydrothermal fluids and $\mathrm{OH}^{-}$to form an alkaline environment that promotes the dissolution of $\mathrm{SiO}_{2}$ [62]. Elements such as $\mathrm{Fe}$, $\mathrm{Mn}$, and $\mathrm{Cr}$ in the source rocks are all elements with variable valence states, which can migrate in a reducing environment. Therefore, we speculate that the quartz overgrowths are rich in $\mathrm{Mn}$ and other elements, owing to the effects of reducing hydrocarbon-bearing fluids. This process can be described by the following chemical equations [62]:

$$
\begin{gathered}
2 \mathrm{MnO}_{2}+\mathrm{CH}_{2} \mathrm{O}+\mathrm{H}_{2} \mathrm{O} \rightleftharpoons 2 \mathrm{Mn}^{2+}+\mathrm{CO}_{2}+4 \mathrm{OH}^{-} \\
\mathrm{Mn}^{2+}+2 \mathrm{OH}^{-}+1 / 2 \mathrm{O}_{2} \rightleftharpoons \mathrm{MnO}_{2}+\mathrm{H}_{2} \mathrm{O}
\end{gathered}
$$

During the process of hydrocarbon generation, a large amount of organic acids will be discharged along with hydrocarbons, which can promote the dissolution of feldspar and carbonates and thus form dissolution pores [63-65]. This is of significance in the formation and transformation of reservoirs and is also a common model for the formation of feldspar-rich reservoirs in lacustrine basins in eastern China (e.g., the Bohai Bay Basin [39]). However, in some areas of western China, such as the Sichuan and Junggar Basins [66-68], alkaline fluids are considered to have caused the dissolution of quartz during burial. The edges of quartz grains in the Baikouquan Formation have been dissolved and replaced by clay minerals (Figure 2). Most of these quartz grains exhibit features of multiphase growth and contain abundant fluid inclusions, which were related to late fluid activity (Figure 2).

Quartz is relatively stable in acidic and neutral environments but is more easily dissolved in alkaline solutions, especially at higher $\mathrm{pH}$ values $[69,70]$. Experimental studies have shown that when the $\mathrm{pH}$ exceeds 6-7, the dissolution rate of quartz increases rapidly, thus forming curved quartz edges [71]. At higher temperatures and pressures, quartz is also more readily dissolved [72]. Clastic sediments experience the syngenetic, early diagenetic, and late diagenetic stages from the onset of sedimentation through to the earliest metamorphism [72]. Due to the effects of organic matter evolution and fluid-rock reaction in each stage, the fluid $\mathrm{pH}$ will increase $[73,74]$. Therefore, alkaline fluids form because of 


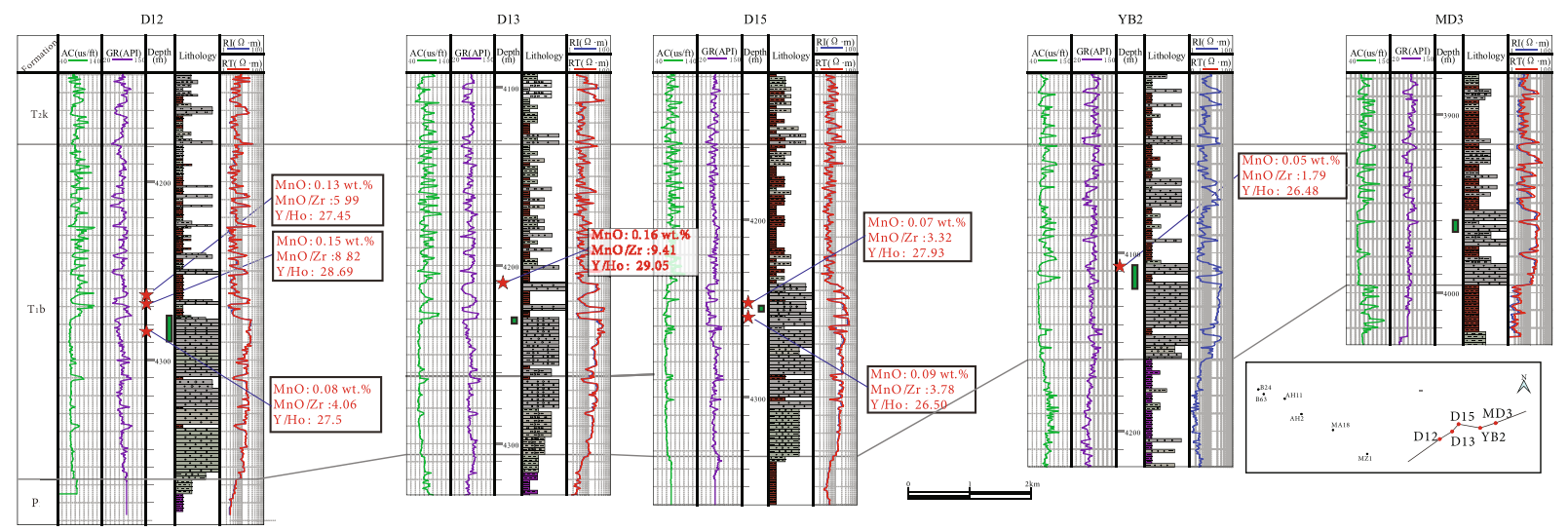

(a)

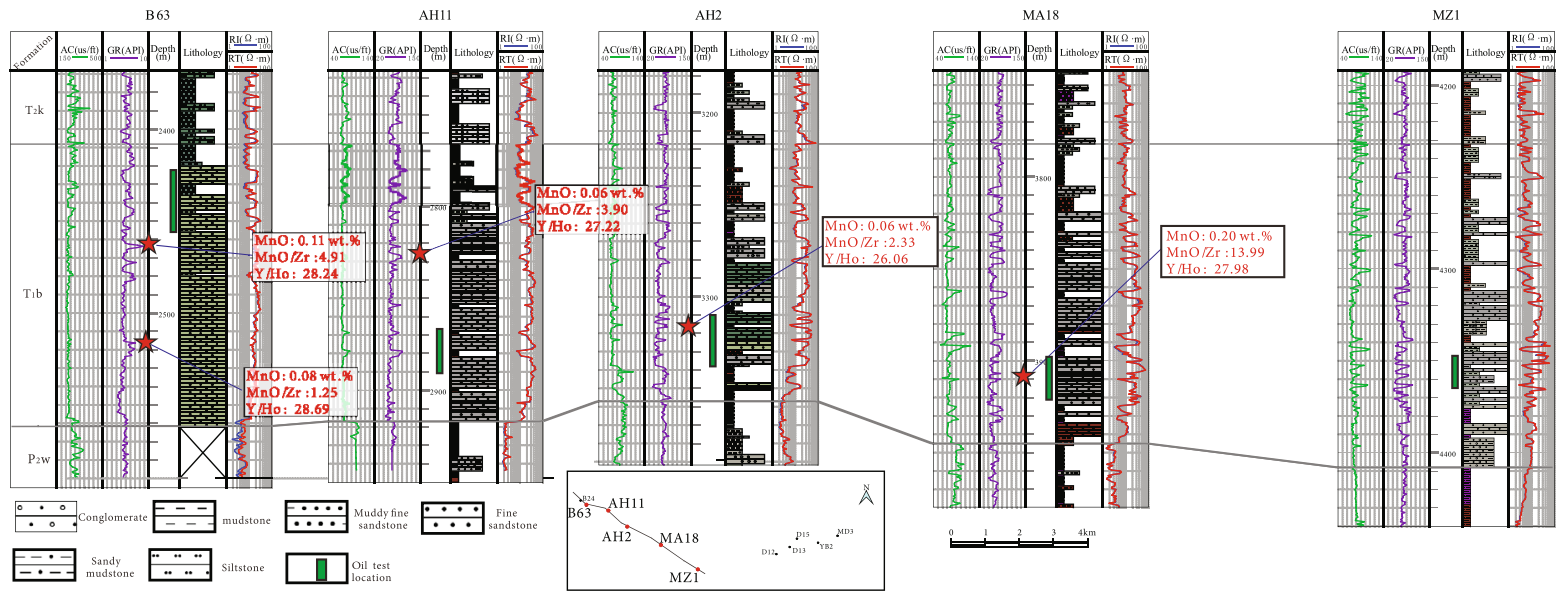

(b)

FIGURE 9: (a) D12-D13-D15-YB2-MD3 tracing indicators (MnO, MnO/Zr, and Y/Ho) that connect the well profiles. (b) B63-AH11-AH2MA18-MZ1 tracing indicators $(\mathrm{MnO}, \mathrm{MnO} / \mathrm{Zr}$, and $\mathrm{Y} / \mathrm{Ho})$ that connect the well profiles.

burial diagenesis in clastic rocks [69-72]. Acid-labile minerals such as calcite and dolomite can be formed and preserved as cements in most clastic rock reservoirs, which also demonstrates that alkaline formation waters existed. Early and late carbonate cements in clastic rock reservoirs possibly reflect multiphase activity of alkaline fluids. It is known that the Mahu Sag was an alkaline lake basin in the Permian [68], which provided favorable conditions for the dissolution of quartz and formation of quartz overgrowths.

5.2. Implications for Hydrocarbon Migration. Given that a large number of elements are mobile in fluids, when fluids interact with rocks, the elements in the fluids can be partially incorporated into quartz overgrowths, thus resulting in elemental enrichment. Therefore, the distribution and enrichment of elements in authigenic minerals can indicate whether fluids have migrated through rocks and can also be used to infer the direction of hydrocarbon migration.

Based on our in situ geochemical data for quartz, we selected several proxies, including $\mathrm{MnO}$ contents and $\mathrm{MnO} / \mathrm{Zr}$ and $\mathrm{Y} / \mathrm{Ho}$ ratios, to examine the migration of hydrocarbon-bearing fluids in the Mahu Sag. The MnO contents tend to decrease from the center to the outer margin of the sag (Figure $8(\mathrm{a})$ ). Those $\mathrm{MnO}$ contents to the south of wells MA18 and D18 are high and gradually decrease to the slope regions in the north, west, and east. The $\mathrm{MnO}$ contents on the western slope are slightly higher than those on the eastern slope. The reason for these differences is that Mn tends to concentrate in the center of a sedimentary basin, and $\mathrm{MnO}$ is then likely to be migrated away by hydrothermal fluids [47, 48]. Therefore, the direction in which the $\mathrm{MnO}$ contents decrease might have been a fluid migration pathway. Basin-scale pressure coefficient contours show that the distribution of $\mathrm{MnO}$ is consistent with the pressure coefficients, particularly near wells D12-D13-D15, MA18-AH2, and MA22. This reveals a trend of hydrocarbon migration towards the $(\mathrm{N}) \mathrm{NE}$ and NW, which is also consistent with the distribution of the Triassic hydrocarbon reservoir (Figure 8(a)). For the trace elements, the chemically active elements also show a gradual change from the center to the margin of the sag. For example, Sr contents also increase to the NW and NE (Figure 8(b)), similar to MnO.

Inorganic geochemical proxies were used to investigate the fluid migration according to the distribution of these chemically active elements. For example, the $\mathrm{MnO} / \mathrm{Zr}$ ratio was used as $\mathrm{Zr}$ which is a fluid-immobile element [62], which is also supported by the in situ geochemical data (Figures 4(c) and $4(\mathrm{~d})$ ), whereas Mn was fluid-mobile (Figures 4 and 5). 
$\mathrm{MnO} / \mathrm{Zr}$ values decrease gradually from the center to the margin of the sag, and changes also occurred near wells DA12-DA13-DA15, MA18-AH2, and MA22 (Figure 8(c)), similar to the $\mathrm{MnO}$ contents. $\mathrm{MnO} / \mathrm{Zr}$ values have a similar distribution to the pressure coefficients and also reveal fluid migration to the (N)NE and NW.

Yttrium and Ho typically exist exclusively as trivalent elements, with similar ionic radii of $\mathrm{Y}^{3+}=0.900 \AA$ and $\mathrm{Ho}^{3+}=$ $0.901 \AA$ [75]. Therefore, $Y$ and Ho often exhibit identical geochemical behavior in geological environments [76]. Previous studies have shown that partial melting and fractional crystallization cannot fractionate $\mathrm{Y}$ and $\mathrm{Ho}$, and the $\mathrm{Y} / \mathrm{Ho}$ ratio in igneous rocks is $\sim 28$ [77]. However, these two elements may be significantly fractionated in aqueous solutions [76], such as in seawater, river water, and hydrothermal fluids. The Y/Ho ratios of the studied samples vary widely (Table 4 ), suggesting that the samples experienced strong fluid-rock interactions. The $\mathrm{Y} / \mathrm{Ho}$ ratios tend to decrease toward the margin of the sag (Figure $8(\mathrm{~d})$ ). As such, Y/Ho ratios also reveal a migration direction to the (N)NE and NW.

Well correlations also reflect the trends of hydrocarbon migration. On the east slope of the Mahu Sag (Figure 9(a)), $\mathrm{MnO}, \mathrm{MnO} / \mathrm{Zr}$, and $\mathrm{Y} / \mathrm{Ho}$ decrease gradually from the center to the margin of the sag, suggesting that rocks in the wells on the hydrocarbon migration pathways were subjected to strong fluid-rock interactions. For rocks in wells on the west slope (Figure 9(b)), $\mathrm{MnO}, \mathrm{MnO} / \mathrm{Zr}$, and $\mathrm{Y} / \mathrm{Ho}$ tend to decrease.

Our results are also consistent with the hydrocarbon migration inferred from organic geochemistry proxies, such as diasterane/regular sterane and $\mathrm{C}_{30}$ moretane/ $\mathrm{C}_{30}$ hopane ratios, and oil exploration results (Figure 8), which show that the western slope is the preferred area for hydrocarbon exploration.

Organic matter in sediments becomes buried and forms source rocks and hydrocarbons. Most studies have used organic geochemistry proxies to infer hydrocarbon migration pathways $[19,20]$. However, organic geochemistry proxies are affected by heat and biodegradation effects in geological environments, and these indicators may not be robust in complex geological settings. Previous studies have found that Mnrich calcite veins are efficient in tracing possible fluid migration pathways in fault zones of the Junggar Basin, and these processes are consistent with the formation of $\mathrm{Mn}$-depleted and Mn-enriched pore waters [47, 48]. This demonstrates that inorganic geochemical methods are another way to investigate hydrocarbon migration. Our study also shows that the distribution of elements can be recorded by quartz overgrowths.

Hydrocarbon migration from source rocks to reservoirs is usually accompanied by the migration of hydrothermal fluids, which can also form hydrocarbon and brine inclusions. Hydrothermal fluids can infill cracks, faults, and unconformities with vein minerals and also enter pores and chemically react with minerals causing mineral dissolution and the formation of authigenic minerals. Based on our inorganic geochemical study of quartz in the Baikouquan Formation in the Mahu Sag, samples on the migration pathway of hydrocarbon-bearing fluids formed authigenic minerals through fluid-rock interactions, which resulted in the exchange and enrichment of certain elements. The fluids evolved with migration distance, with different element enrichments, showing that inorganic elements are affected by the migration of hydrocarbon-bearing fluids. Therefore, our methodology provides a new means for tracing hydrocarbon-bearing fluid migration.

\section{Summary and Conclusions}

We conducted a petrological and geochemical study of reservoir rocks of the Triassic Baikouquan Formation from the slope of the Mahu Sag, Junggar Basin. Our results show that inorganic geochemical data can track the migration of hydrocarbon-bearing fluids.

The sandy conglomerate samples on the hydrocarbonbearing fluid migration pathways underwent strong fluidrock interactions, with formation of clay minerals, and quartz dissolution and overgrowths.

Chemically active elements, such as $\mathrm{Mn}, \mathrm{Fe}, \mathrm{Al}, \mathrm{Sr}$, and $\mathrm{W}$, have higher contents in quartz overgrowths than in quartz cores, implying that these elements were supplied by hydrocarbon-bearing hydrothermal fluids.

$\mathrm{MnO}$ contents and $\mathrm{Mn} / \mathrm{Zr}$ and $\mathrm{Y} / \mathrm{Ho}$ ratios can be used to reconstruct the hydrocarbon migration and accumulation pathways. The direction in which these contents and ratios decrease can indicate the potential direction of hydrocarbon-bearing fluid migration. More studies from different settings would refine the results and understandings of the present study.

\section{Data Availability}

The data used to support the findings of this study are available from the corresponding author upon request.

\section{Conflicts of Interest}

The authors declare that they have no conflicts of interest.

\section{Acknowledgments}

We would like to express our sincere thanks to PetroChina Xinjiang Oilfield Company for providing core samples and data such as formation pressure and density of crude oil. Besides, our heartfelt thanks are also expressed to the Major National Science and Technology Project (Grant Nos. 2017ZX05001 and 2016ZX03003) and National Natural Science Foundation of China (Grant No. 41702138) which provide funding for the research work.

\section{References}

[1] M. M. Thomas and J. A. Clouse, "Scaled physical model of secondary oil migration," AAPG Bulletin, vol. 79, no. 1, pp. 19-28, 1995.

[2] P. Meakin, G. Wagner, A. Vedvik, H. Amundsen, J. Feder, and T. Jøssang, "Invasion percolation and secondary migration: experiments and simulations," Marine and Petroleum Geology, vol. 17, no. 7, pp. 777-795, 2000.

[3] Z. X. Jiang, X. Q. Pang, J. H. Zeng, H. Y. Wang, and Q. Luo, "Research on types of the dominant migration pathways and their physical simulation experiments," Earth Science Frontiers, vol. 12, no. 4, pp. 507-516, 2005. 
[4] S. H. Zhang, M. H. Yang, and X. H. Luo, "Hydrocarbon episodic migration in fault zones: insights from physical simulation experiments," Geological Review, vol. 65, no. 5, pp. 1183-1191, 2015.

[5] Y. C. Zhang, J. H. Zeng, Z. X. Dai et al., "Experimental investigation on oil migration and accumulation in tight sandstones," Journal of Petroleum Science and Engineering, vol. 160, pp. 267-275, 2018.

[6] Y.S. Zhou and R. Littke, "Numerical simulation of the thermal maturation, oil generation and migration in the Songliao Basin, Northeastern China," Marine and Petroleum Geology, vol. 16, no. 8, pp. 771-792, 1999.

[7] X. Luo, "Simulation and characterization of pathway heterogeneity of secondary hydrocarbon migration," AAPG Bulletin, vol. 95, no. 6, pp. 881-898, 2011.

[8] J. Gusterhuber, R. Hinsch, and R. F. Sachsenhofer, "Evaluation of hydrocarbon generation and migration in the molasse fold and thrust belt (Central Eastern Alps, Austria) using structural and thermal basin models," AAPG Bulletin, vol. 98, no. 2, pp. 253-277, 2014.

[9] X. R. Luo, C. Z. Hu, Z. Y. Xiao et al., "Effects of carrier bed heterogeneity on hydrocarbon migration," Marine and Petroleum Geology, vol. 68, pp. 120-131, 2015.

[10] T. Wang, S. Dong, S. Wu, H. Xu, and P. Hou, "Numerical simulation of hydrocarbon migration in tight reservoir based on Artificial Immune Ant Colony Algorithm: a case of the Chang $8_{1}$ reservoir of the Triassic Yanchang Formation in the Huaqing area, Ordos Basin, China," Marine and Petroleum Geology, vol. 78, pp. 17-29, 2016.

[11] Q. L. Guo, J. F. Liu, N. S. Chen et al., "Mesh model building and migration and accumulation simulation of 3D hydrocarbon carrier system," Petroleum Exploration and Development, vol. 45, no. 6, pp. 947-959, 2018.

[12] C. Herdes, C. Petit, A. Mejía, and E. A. Müller, "Combined experimental, theoretical, and molecular simulation approach for the description of the fluid-phase behavior of hydrocarbon mixtures within shale rocks," Energy \& Fuels, vol. 32, no. 5, pp. 5750-5762, 2018.

[13] A. D. Hindle, "Petroleum migration pathways and charge concentration: a three-dimensional model 1," AAPG Bulletin, vol. 81, no. 9, pp. 1451-1481, 1997.

[14] M. Lee and D. D. Williams, "Paleohydrology of the Delaware Basin, Western Texas: overpressure development, hydrocarbon migration, and ore genesis," AAPG Bulletin, vol. 84, no. 7, pp. 961-974, 2000.

[15] Z. H. Chen, K. G. Osadetz, D. R. Issler, and S. E. Grasby, "Hydrocarbon migration detected by regional temperature field variations, Beaufort-Mackenzie Basin, Canada," AAPG Bulletin, vol. 92, no. 12, pp. 1639-1653, 2008.

[16] M. Baron, J. Parnell, D. Mark, A. Carr, M. Przyjalgowski, and M. Feely, "Evolution of hydrocarbon migration style in a fractured reservoir deduced from fluid inclusion data, Clair Field, west of Shetland, UK," Marine and Petroleum Geology, vol. 25, no. 2, pp. 153-172, 2008.

[17] Y. M. Makeen, W. H. Abdullah, M. J. Pearson, M. H. Hakimi, O. M. A. Elhassan, and Y. T. Hadad, "Thermal maturity history and petroleum generation modelling for the Lower Cretaceous Abu Gabra Formation in the Fula Sub-basin, Muglad Basin, Sudan," Marine and Petroleum Geology, vol. 75, pp. 310-324, 2016.

[18] J. Chang, N. Qiu, X. Zhao, F. Shen, N. Liu, and W. Xu, "Mesozoic and Cenozoic tectono-thermal reconstruction of the west- ern Bohai Bay Basin (East China) with implications for hydrocarbon generation and migration," Journal of Asian Earth Sciences, vol. 160, pp. 380-395, 2018.

[19] L. B. Williams, R. E. Ferrell, I. Hutcheon, A. J. Bakel, M. M. Walsh, and H. R. Krouse, "Nitrogen isotope geochemistry of organic matter and minerals during diagenesis and hydrocarbon migration," Geochimica et Cosmochimica Acta, vol. 59, no. 4, pp. 765-779, 1995.

[20] D. J. Byrne, P. H. Barry, M. Lawson, and C. J. Ballentine, "The use of noble gas isotopes to constrain subsurface fluid flow and hydrocarbon migration in the East Texas Basin," Geochimica et Cosmochimica Acta, vol. 268, pp. 186-208, 2020.

[21] R. K. Bian, J. C. Zhang, X. Tang et al., "Characteristics of energy fields and the hydrocarbon migration-accumulation in deep strata of Tahe Oilfield, Tarim Basin, NW China," Petroleum Exploration and Development, vol. 37, pp. 416423, 2010.

[22] C. L. Li, P. Guo, and D. S. Ren, "Relationship between tectonic stress field and migration and accumulation of oil and gas in Damintun depression," Petroleum Geology and Recovery Efficiency, vol. 19, no. 6, pp. 47-49, 2012.

[23] W. T. Zeng, J. C. Zhang, W. L. Ding et al., "Fracture development in Paleozoic shale of Chongqing area (South China). Part one: fracture characteristics and comparative analysis of main controlling factors," Journal of Asian Earth Sciences, vol. 75, pp. 251-266, 2013.

[24] T. Tian, Z. L. Ren, X. Q. Wu et al., "The paleogeothermal field and hydrocarbon accumulation period in Sartai depression, Yabrai Basin," Acta Sedimentologica Sinica, vol. 33, no. 4, pp. 836-844, 2015.

[25] H. Liu, C. Jiang, Y. L. Liu, F. F. Yuan, and H. Lu, “Optimization of hydrocarbon migration parameters and identification of migration pattern," Petroleum Geology \& Experiment, vol. 40, no. 3, pp. 424-430, 2018.

[26] L. F. Liu and Y. S. Kang, "Investigation on secondary migration of oils in central tarim basin using pyrrolic nitrogen conpounds," Geochimica, vol. 27, no. 5, pp. 475-482, 1998.

[27] T. G. Wang, S. M. Li, A. Y. Zhang, L. Zhu, B. H. Li, and Y. B. Zhou, "Oil migration analysis with pyrrolic nitrogen compounds," Journal of the University of Petroleum, China, vol. 24, no. 4, pp. 83-87, 2000.

[28] C. F. Xiang, B. Xia, X. N. Xie, Z. Q. Feng, and H. Y. Wu, "Tracing hydrocarbon migration by integrated analysis of different kinds of tracers in western slope zone of Songliao Basin, Northeast China," Geological Science and Technology Information, vol. 23, pp. 64-70, 2004.

[29] B. Z. Shan, "The application of nitric compound research in tracing hydrocarbon migration in Liangjialou oilfield," Xinjiang Oil \& Gas, vol. 1, no. 2, pp. 19-21, 2005.

[30] J. J. Li, D. Z. Tang, and Y. Y. Yang, "Migration tracing mechanism of carbazole compounds and its application," Petroleum Geology and Recovery Efficiency, vol. 15, no. 5, pp. 38-41, 2008.

[31] Q. W. Pang, Q. Zhen, Y. Qin, and H. Fu, “Tracer analysis of hydrocarbon migration in Baijiahai arch-Fubei slope of Junggar Basin," Journal of Yangtze University(Natural Science Edition), vol. 8, no. 12, pp. 40-43, 2011.

[32] W. A. England, "Secondary migration and accumulation of hydrocarbons," The Petroleum System-From Source to Trap, L. B. Magoon and W. G. Dow, Eds., pp. 211-217, 1994.

[33] D. A. Karlsen, J. E. Skeie, and K. Backer-owe, "Petroleum migration, faults and overpressure. Part II. Case history: the 
Hltenbanken Petroleum Province, offshore Norway," Understanding Petroleum Reservoirs: Towards an Integrated Reservoir Engineering and Geochemical Approach, J. M. Cubitt, W. A. England, and S. R. Larter, Eds., vol. 237, pp. 305-372, 2004.

[34] M. Bau, "Rare-earth element mobility during hydrothermal and metamorphic fluid-rock interaction and the significance of the oxidation state of europium," Chemical Geology, vol. 93, no. 3-4, pp. 219-230, 1991.

[35] J. V. Goddard and J. P. Evans, "Chemical changes and fluidrock interaction in faults of crystalline thrust sheets, northwestern Wyoming, U.S.A.," Journal of Structural Geology, vol. 17, no. 4, pp. 533-547, 1995.

[36] C. I. Steefel and K. Maher, "Fluid-rock interaction: a reactive transport approach," Reviews in Mineralogy and Geochemistry, vol. 70, no. 1, pp. 485-532, 2009.

[37] J. Schieber, K. Dave, and R. Lee, "Diagenetic origin of quartz silt in mudstones and implications for silica cycling," Nature, vol. 406, no. 6799, pp. 981-985, 2000.

[38] A. Hyodo, R. Kozdon, A. D. Pollington, and J. W. Valley, "Evolution of quartz cementation and burial history of the Eau Claire Formation based on in situ oxygen isotope analysis of quartz overgrowths," Chemical Geology, vol. 384, pp. 168180, 2014.

[39] G. Yuan, Y. Cao, J. Gluyas, X. Cao, and W. Zhang, "Petrography, fluid-inclusion, isotope, and trace-element constraints on the origin of quartz cementation and feldspar dissolution and the associated fluid evolution in arkosic sandstones," $A A P G$ Bulletin, vol. 102, no. 5, pp. 761-792, 2018.

[40] O. J. Oye, A. C. Aplin, S. J. Jones et al., "Vertical effective stress as a control on quartz cementation in sandstones," Marine and Petroleum Geology, vol. 98, pp. 640-652, 2018.

[41] D. Emery, J. D. Hudson, and J. D. Marshall, "The origin of late spar cements in the Lincolnshire limestone, Jurassic of Central England," Journal of the Geological Society of London, vol. 145, no. 4, pp. 621-633, 1988.

[42] J. R. Boles, P. Eichhubl, and G. Garven, "Evolution of a hydrocarbon migration pathway along basin-bounding faults: evidence from fault cement," AAPG Bulletin, vol. 88, no. 7, pp. 947-970, 2004.

[43] M. Y. Zhu, X. Zhen, X. S. Liu, and W. Z. Zhang, "Stable carbon isotope of authigenetic calcite used in reservoirs to tracing the hydrocarbon migration," Natural Gas Industry, vol. 27, no. 9, pp. 24-27, 2007.

[44] J. Cao, W. X. Hu, S. P. Yao et al., "Manganese in reservoir calcite cement and its implication for tracing oil migration in Junggar Basin," Acta Petrolei Sinica, vol. 30, pp. 705-710, 2009.

[45] J. Cao, Z. J. Jin, W. X. Hu et al., "Improved understanding of petroleum migration history in the Hongche fault zone, northwestern Junggar Basin (northwest China): constrained by vein-calcite fluid inclusions and trace elements," Marine and Petroleum Geology, vol. 27, no. 1, pp. 61-68, 2010.

[46] M. B. Allen and S. J. Vincent, "Fault reactivation in the Junggar region, northwest China: the role of basement structures during Mesozoic-Cenozoic compression," Journal of the Geological Society, vol. 154, no. 1, pp. 151-155, 1997.

[47] J. M. Zhao, Y. Huang, Z. J. Ma et al., "Discussion on the basement structure and property of northern Junggar Basin (in Chinese with English abstract)," Chinese Journal of Geophysics, vol. 51, no. 6, pp. 1767-1775, 2008.

[48] X. H. Chen, F. Lu, L. S. Shu, H. M. Wang, and G. Q. Zhang, "Study on tectonic evolution analysis of Junggar Basin (in Chi- nese with English abstract)," Geological Journal of China Universities, vol. 8, pp. 257-267, 2002.

[49] D. F. He, C. Z. Jia, X. Y. Zhou et al., "Control principles of structures and tectonics over hydrocarbon accumulation and distribution in multi-stage superimposed basins (in Chinese with English abstract)," Acta Petrolei Sinica, vol. 26, pp. 1-9, 2005.

[50] X. Q. Pang, X. R. Luo, Z. X. Jang et al., "Advancements and problems on hydrocarbon accumulation research of complicated superimposed basins in western China (in Chinese with English abstract)," Advances in Earth Science, vol. 27, pp. 879887, 2007.

[51] Y. T. Wang and S. B. Jiang, "Deep origin and exploration for the hydrocarbon of the Lunan uplift on the hinterland of the Junggar Basin (in Chinese with English abstract)," Experimental Petroleum Geology, vol. 21, pp. 34-40, 1999.

[52] X. L. Wang and S. F. Kang, "Analysis on the oil source of the Mabei oilfield of northwest Junggar Basin (in Chinese with English abstract)," Journal of Southwest Petroleum Institute, vol. 23, pp. 6-9, 2001.

[53] J. P. Chen, X. L. Wang, C. P. DENG et al., "Geochemical features of source rocks and crude oil in the Junggar Basin, northwest China," Acta Geologica Sinica, vol. 90, no. 1, pp. 37-67, 2016.

[54] J. Cao, L. Xia, T. Wang, D. Zhi, Y. Tang, and W. Li, “An alkaline lake in the Late Paleozoic Ice Age (LPIA): a review and new insights into paleoenvironment and petroleum geology," Earth-Science Reviews, vol. 202, article 103091, 2020.

[55] C. H. Gao, M. Zha, J. X. Qu, and X. J. Ding, "Fluid inclusion characteristics and hydrocarbon accumulation stages of unconformable reservoirs in the northwest margin of the Junggar Basin," Natural Gas Industry, vol. 35, no. 11, pp. 2332, 2015.

[56] W. F. McDonough and S. S. Sun, "The composition of the Earth," Chemical Geology, vol. 120, no. 3-4, pp. 223-253, 1995.

[57] S. R. Taylor and S. M. McLennan, "The geochemical evolution of the continental crust," Reviews of Geophysics, vol. 33, no. 2, pp. 241-265, 1995.

[58] D. R. Gray, R. T. Gregory, and D. W. Durney, "Rock-buffered fluid-rock interaction in deformed quartz-rich turbidite sequences, eastern Australia," Journal of Geophysical Research: Solid Earth, vol. 96, no. B12, pp. 19681-19704, 1991.

[59] White, Geochemistry, Wiley, 2007.

[60] R. C. Surdam, L. J. Crossey, and E. S. Hagen, "Organic-inorganic interactions and sandstone diagenesis," AAPG Bulletin, vol. 77, no. 1, pp. 1-23, 1989.

[61] R. C. Surdam and H. P. Heasler, Techniques for the Delineation of Liquid Hydrocarbon Resources Using Maturation and Enhanced Eeservoir Porosity Models, Wyoming University, Laramie, WY (United States), 1990.

[62] R. K. Stoessell and E. D. Pittman, "Secondary porosity revisited: the chemistry of feldspar dissolution by carboxylic acids and anions," AAPG Bulletin, vol. 74, no. 12, pp. 1795-1805, 1990.

[63] K. G. Knauss and T. J. Wolery, "The dissolution kinetics of quartz as a function of $\mathrm{pH}$ and time at $70^{\circ} \mathrm{C}$," Geochimica et Cosmochimica Acta, vol. 52, no. 1, pp. 43-53, 1988.

[64] P. M. Dove and D. A. Crerar, "Kinetics of quartz dissolution in electrolyte solutions using a hydrothermal mixed flow reactor," Geochimica et Cosmochimica Acta, vol. 54, no. 4, pp. 955-969, 1990. 
[65] F. K. Crundwell, "On the mechanism of the dissolution of quartz and silica in aqueous solutions," ACS Omega, vol. 2, no. 3, pp. 1116-1127, 2017.

[66] L. W. Qiu and Z. X. Jiang, Alkaline Diagenesis of Terrigenous Clastic Rocks, Geological Press, Beijing, 2006.

[67] K. B. Sullivan and E. F. McBride, "Diagenesis of sandstones at shale contacts and diagenetic heterogeneity, Frio Formation, Texas," AAPG Bulletin, vol. 75, no. 1, pp. 121-138, 1991.

[68] J. M. Zheng and F. X. Ying, "Reservoir characteristics and diagenetic model of sandstone intercalated in coal-bearing strata (acid water medium)," Acta Petrolei Sinica, vol. 18, no. 4, pp. 19-24, 1997.

[69] K. Yu, Y. Cao, L. Qiu, and P. Sun, "Depositional environments in an arid, closed basin and their implications for oil and gas exploration: the lower Permian Fengcheng Formation in the Junggar Basin, China," AAPG Bulletin, vol. 103, no. 9, pp. 2073-2115, 2019.

[70] L. Xia, J. Cao, M. Wang, J. Mi, and T. Wang, "A review of carbonates as hydrocarbon source rocks: basic geochemistry and oil-gas generation," Petroleum Science, vol. 16, pp. 713-728, 2019.

[71] M. Bau and P. Dulski, "Comparative study of yttrium and rareearth element behaviours in fluorine-rich hydrothermal fluids," Contributions to Mineralogy and Petrology, vol. 119, no. 2-3, pp. 213-223, 1995.

[72] E. Anders and N. Grevesse, "Abundances of the elements: meteoritic and solar," Geochimica Et Cosmochimica Acta, vol. 53, no. 1, pp. 197-214, 1989.

[73] M. Bau, P. Mller, and P. Dulski, "Yttrium and lanthanides in eastern Mediterranean seawater and their fractionation during redox-cycling," Marine Chemistry, vol. 56, no. 1-2, pp. 123131, 1997.

[74] G. D. Liu, G. Gao, Z. L. Huang, and H. F. Yang, "Oil source and accumulation in the overthrust belt in the Ke-Bai region, Junggar Basin, West China," Petroleum Science, vol. 7, no. 1, pp. 31-39, 2010.

[75] A. G. Wang, L. P. Yi, B. L. Xiang et al., "Origin of deep heavy oils in the northwestern Junggar Basin (NW China) and implications for gas migration," Energy Exploration \& Exploitation, vol. 38, no. 4, pp. 819-840, 2020.

[76] A. L. Ma, "Advancement in application of diamondoids on organic geochemistry," Journal of Natural Gas Geoscience, vol. 1, no. 4, pp. 257-265, 2016.

[77] G. N. Gordadze, V. Y. Kerimov, A. V. Gaiduk et al., "Hydrocarbon biomarkers and diamondoid hydrocarbons from late Precambrian and lower Cambrian rocks of the Katanga saddle (Siberian platform)," Geochemistry International, vol. 55, no. 4, pp. 360-366, 2017.

[78] M. Niwa, Y. Mizuochi, and A. Tanase, "Changes in chemical composition caused by water-rock interactions across a strike-slip fault zone: case study of the Atera fault, Central Japan," Geofluids, vol. 15, no. 3, pp. 387-409, 2015.

[79] Z. Y. Zhao, J. H. Zhao, H. J. Wang, J. D. Liao, and C. M. Liu, "Distribution characteristics and applications of trace elements in Junggar Basin," Natural Gas Exploration and Development, vol. 30, no. 2, pp. 30-32, 2007. 